\title{
The interaction of monetary and macroprudential policies in economic stabilisation
}

\author{
Aino Silvo \\ University of Helsinki and HECER
}

Discussion Paper No. 395

September 2015

ISSN 1795-0562

HECER - Helsinki Center of Economic Research, P.O. Box 17 (Arkadiankatu 7), FI-00014 University of Helsinki, FINLAND, Tel +358-2941-28780, E-mail info-hecer@helsinki.fi, Internet www.hecer.fi 


\title{
The interaction of monetary and macroprudential policies in economic stabilisation*
}

\begin{abstract}
I analyse the dynamics of a New Keynesian DSGE model where the financing of investments is affected by a moral hazard problem. I solve for jointly Ramsey-optimal monetary and macroprudential policies. I find that when there is a financial friction besides the standard nominal friction, the optimal policy can replicate the first-best if the social planner can conduct both monetary and macroprudential policy to control both inflation and the level of investments. Using monetary policy alone is not enough to fully stabilise the economy: it leads to a policy trade-off between stabilising inflation and the output gap. When policy follows simple rules instead, the source of fluctuations is highly relevant for the choice of the appropriate policy mix.
\end{abstract}

JEL Classification: E32, E44, E52, G28

Keywords: monetary policy, macroprudential policy, financial frictions

Aino Silvo

Department of Political and Economic Studies

University of Helsinki

P.O. Box 17 (Arkadiankatu 7)

FI-00014 University of Helsinki

FINLAND

e-mail: aino.silvo@helsinki.fi

* I wish to thank my supervisor Antti Ripatti as well as Markus Haavio and Tuomas Takalo for their guidance and suggestions. I also thank Harri Turunen, Jaakko Nelimarkka, and participants at the HECER workshops, the Finnish Economic Association Annual Meeting, the NHH-UiO Macro workshop and the Nordic Macro Symposium at Smögen for useful comments. I am grateful for financial support from the Yrjö Jahnsson Foundation and the OP-Pohjola Group Research Foundation. 


\section{Introduction}

The global financial crisis that erupted in 2007 in the U.S. has highlighted the importance of aggregate balance sheet conditions of banks for economic cycles. As a response to the crisis, policymakers have emphasised the importance of macroprudential regulation, as opposed to and in addition of reforms to the regulation and supervision of individual institutions (see, for example, the policy reports by the Bank of England (2009) and the Bank of International Settlements (2011)).

The main contribution of this research paper is to solve for the Ramseyoptimal mix of monetary and macroprudential policies in response to various economic and financial disturbances, and to analyse the welfare effects of jointly setting these policies. I find that the first-best optimal outcome can be replicated when a social planner can jointly use both a monetary and a macroprudential instrument. On the contrary, using only monetary policy leads to a policy trade-off between stabilising inflation and output gap. I also compare the performance of rule-based policies to the Ramsey-optimal policies.

Macroprudential policy refers to policy measures that aim at mitigating the risks and imbalances of the financial system as a whole, while conventional microprudential banking regulation has focused on single institutions. The mitigation of credit cycles, which tend to be much more volatile than real output cycles, has been seen as a key policy goal for the new macroprudential framework. This regulatory response stems from the widespread view that a build-up of system-wide risks and imbalances was at the heart of the collapse of the financial system in 2007. In this view, mitigating credit cycles and supporting financial stability are important policy goals in themselves, but also essential for the stability of the economy as a whole, as banking crises tend to have long-lasting consequences for real economic activity.

Suggested new macroprudential policy tools include, among others, countercyclical and risk-weighted capital buffers for banks, that depend not only on the banks' own balance sheet conditions, but on aggregate credit and other economic conditions. This new policy framework was internationally adopted in the Basel III agreement in 2010 (Basel Committee on Banking Supervision 2010). 
As the crisis unfolded, many banks both in the U.S. and in Europe were bailed out or recapitalised by governments. In the Euro Area, a new regulatory framework (the "banking union") was set up. It includes both common supervision of individual financial institutions, as well as a common bank resolution mechanism, which entered into force in 2014. This Single Resolution Mechanism will be funded by contributions from the financial institutions themselves, in proportion to the size of their balance sheet, with the purpose of minimising the costs of future bank failures on the real economy (see European Commission 2012).

In this paper, I analyse the interaction of interest-rate-based monetary policy with macroprudential regulation in the stabilisation of economic cycles. I formulate a DSGE model where the banks' balance sheets play a key role in financial intermediation, which in turn has an important effect on economic cycles. These dynamics arise because of informational frictions in credit intermediation caused by a particular agency problem, as formulated by Holmström and Tirole (1997).

The key transmission channel from the financial sector to the real economy is the real capital price, which on the one side affects invesment decisions in the financial market, and on the other side household's saving behaviour. The fluctuations of this price summarise the effects that the agency cost has on the availability of capital and investments in the economy.

In the Ramsey policy problem I formulate, a social planner has either one policy variable (the inflation rate), or two policy variables (the inflation rate and the level of investments) that he can directly set. The problem of the planner is constrained in the sense that he cannot remove the agency costs in the economy. The planner's objective is to maximise the household's lifetime welfare.

The main contribution of this paper is the justification for a separate macroprudential policy, which the solution to the Ramsey problem provides. With two policy variables, the planner can replicate the first-best outcome, which is the flexible price real business cycle $(\mathrm{RBC})$ equilibrium. There are no policy trade-offs.

With only one policy variable however, the planner cannot replicate the $\mathrm{RBC}$ outcome, leading to an inefficient optimum. There is in this case a 
policy trade-off in stabilising inflation, on the one hand, and stabilising the output gap, on the other hand. This result highlights the importance of having separate policy tools to deal with separate frictions - here, the nominal friction on the one hand, and the financial friction on the other. Using only conventional monetary policy that targets the inflation rate is not enough to deal with both the nominal friction and the financial friction simultaneously. The result is also in contrast with the traditional New Keynesian optimal policy literature, where controlling the inflation rate is enough for the planner to replicate the first-best.

Next, I compare the constrained optimum to a set of simple rule-based policies, which are more realistically implementable. I first look at an augmented Taylor rule, where the monetary authority also reacts to financial developments through real asset prices. Then, I analyse conventional Taylor rule policies together with a separate macroprudential tool. One such tool is a cyclical leverage tax/subsidy on banks that aims at smoothing out credit cycles; another is a cyclical tax/subsidy scheme on investment project returns, which stimulates financial investment in recessions. These tax plans aim at approximating the Ramsey-optimal policies in a more easily implementable way.

I find that there are clear benefits from a separate macroprudential policy tool in stabilising the effects of financial disturbances. By controlling the aggregate leverage of the banking sector and smoothing out the credit cycle, the macroprudential policy can effectively prevent the financial shock from propagating to the real economy. In such a case, both the leverage tax and the investment tax turn out to work exactly in the same way.

In contrast, when the disturbances arise from real supply or demand side shocks and not from the financial sector, the form of the macroprudential policy matters, as it can hinder proper economic adjustment by creating an additional friction on the adjustment of investments. Here, taxing investment returns leads to better results (in terms of welfare costs to the households) than a bank leverage tax. A unified mandate for the monetary authority, where besides price developments the central bank also pays attention to financial developments, can be beneficial.

Most theoretical macroeconomic models that deal with policy issues do not 
take the capital position of the financial sector into account, even though there is ample empirical evidence of bank capital affecting economic activity. Even many of the recent dynamic stochastic general equilibrium (DSGE) models of financial frictions abstract from banks' balance sheets. Examples of such studies include Iacoviello (2005), Monacelli (2006), Faia and Monacelli (2007), and Adrian and Shin (2010). All of these articles consider shocks to asset prices and the net worth of the borrower. However, none of them discuss or analyse an explicit financial sector; instead, lending is done directly between lender and borrower without intermediation.

Some more recent research do consider the role of credit intermediation in business cycles. Many of them concentrate on "unconventional" monetary policy tools, in contrast to conventional interest rate policies, such as expanding the balance sheet of the monetary authority (quantitative easing) or direct lending to the private sector by the central bank. Cúrdia and Woodford (2010a, b, 2011) model balance sheets of both the central bank and private banks in a framework of costly financial intermediation. Their results suggest that in a deep enough financial crisis, such unconventional monetary policy measures can be efficient.

Canzoneri et al. (2011) suggest, building on Cúrdia and Woodford (2010a, b, 2011), that financial market frictions can be strongly countercyclical and have amplification effects on business cycles and fiscal multipliers. This finding supports the view that mitigating credit cycles has important consequences for general economic conditions.

Gertler and Kiyotaki (2010) and Gertler and Karadi (2011) also study unconventional monetary policies and find that direct lending by the central bank is an efficient monetary policy tool in mitigating financial turmoil. Gertler and Kiyotaki $(2010,2013)$ extend the model of Gertler and Karadi (2011) to include interbank credit markets. In these models, the moral hazard is generally between the bank and its depositors, affecting the supply side of credit intermediation.

Another strand of literature uses the Holmström-Tirole (1997) double moral hazard framework to explicitly model frictions on both the demand and the supply side of credit intermediation. This approach to modelling agency costs has been used by Chen (2001), Meh and Moran (2010), Christensen 
et al. (2011), and Faia (2010), and most recently by Haavio et al. (2015), on which the present paper builds.

It is not evident how monetary policy should react to financial imbalances - if at all - and how the new macroprudential policy measures should be coordinated with monetary policy over the business cycle. As an example, in an economic upturn, the monetary authority typically wishes to raise interest rates. This will on the one hand increase banks' cost of lending, reining in credit intermediation. On the other hand, high interest rates could have adverse incentive effects. According to the Tinbergen principle, a policymaker should have as many policy instruments as there are policy objectives, and each instrument should be assigned to one objective. In light of this view, then, a separate macroprudential tool could be useful if stabilising credit cycles is an objective of the policymaker. The Ramseyoptimal policy analysis in this paper supports this view.

The literature on jointly optimising monetary and macroprudential policies is not large. Most authors only look at rule-based policies. Angelini et al. (2014) look at an economy with collateral constraints, where a policymaker sets the parameters simple monetary and macroprudential policy rules to maximise an ad-hoc quadratic policy objective. Angeloni and Faia (2013) study jointly optimal rule-based monetary policies and capital regulation using a model of bank runs. Christensen et al. (2011) investigate optimal rule-based capital ratio regulation and monetary policy. With regard to jointly optimal Ramsey policies, Collard et al. (2012) study jointly optimal monetary and macroprudential policies in a model setting where limited liability and deposit insurance cause excess risk-taking in the financial sector. The closest work to the present paper is Christensen et al. (2011). The findings in the present paper are mostly in line with theirs and those of Angelini et al. (2014), who also find modest gains from macroprudential regulation when shocks arise from the supply side, and larger benefits when shocks arise from the financial sector itself. Unlike others, I provide a clear justification for the need and the desirability of a macroprudential policy through the Ramsey policy analysis.

The remainder of the paper is organised as follows. First, Section 2 outlines the theoretical framework. Next, Section 3 presents the calibration and discusses the empirical fit of the model. The main contribution of this paper 
is presented in Section 4, which discusses the implications of the frictions in the financial sector to the aggregate economy and the Ramsey-optimal policy plans that can offset the effects of this friction to restore the firstbest. Next, Section 5 analyses the aggregate dynamics of the model economy under various simple policy rules and compares these policy regimes to the Ramsey policies. Section 6 discusses the welfare implications of the different policy regimes. Finally, Section 7 concludes.

\section{The model}

The model presented in this section builds on the recent work by Haavio, Ripatti, and Takalo (2015). It incorporates into an otherwise fairly standard New Keynesian setup a financial sector afflicted by double moral hazard of the Holmström and Tirole (1997) type, whereby a moral hazard problem exists both between the bank and its depositors, and the bank and its borrowers. This allows for a friction to exist both on the supply and the demand side of credit.

\subsection{Structure of the economy}

The economy consists of atomistic households, a production sector, a financial sector, and a government. The total mass of households is one. Each household has three members with distinct roles: an entrepreneur, a banker, and a worker-consumer ${ }^{1}$. Each banker manages a bank, each entrepreneur undertakes risky projects to produce new capital goods, and each worker supplies labour to firms, consumes final goods, and saves. Intertemporal savings can be invested in riskless government bonds or in productive capital. There is perfect insurance between the family members within a household, so that the model can be described with a representative household.

The production sector is standard to New Keynesian models, except for capital production. There are intermediate good firms and final good firms. Monopolistically competitive intermediate good firms employ capital and

\footnotetext{
${ }^{1}$ The terms "worker-consumer", "worker" and "depositor" will be used interchangeably to denote the family member who is not an entrepreneur or a banker, depending on the specific context.
} 
labour to produce goods, which are then bundled into final goods by perfectly competitive final good firms.

Capital is produced by entrepreneurs, who undertake risky projects to do so. The financial sector takes deposits from households, and issues loans to entrepreneurs, who need funding for their projects. The banks also monitor the entrepreneurs' projects to guarantee efficient use of the funds.

The government issues riskless nominal bonds and conducts monetary and macroprudential policy.

\subsection{Households}

In each period, part of the economy's entrepreneurs and bankers exit. An entrepreneur survives to the next period with a constant probability $\lambda^{e} \in$ $(0,1)$, and exits with probability $1-\lambda^{e}$. A banker's survival probability is, similarly, $\lambda^{b} \in(0,1)$. New entrepreneurs and bankers are born in every period to replace the exiting ones, such that the shares of entrepreneurs and bankers in the economy remain constant over time. Consequently, also the fraction of worker-consumers in the economy stays constant.

While a banker or an entrepreneur is active, they do not consume; they merely engage in their banking or entrepreneurial activities and accumulate net worth. The assumption of finite lives for bankers and entrepreneurs is needed to ensure that they cannot accumulate wealth infinitely. When they exit, their net worth is transferred to their household (to be consumed or saved). A small start-up fund is allocated to each new-born banker and entrepreneur.

The working member of the household consumes, makes saving decisions and portfolio choices, and supplies labour in each period in a standard manner.

The representative household maximises its utility:

$$
\max _{\left\{C_{t}, B_{t+1}, I_{t}, L_{t}\right\}_{t=0}^{\infty}} E_{0} \sum_{t=0}^{\infty} \beta^{t} U\left(C_{t}, L_{t}\right), \quad 0<\beta<1,
$$


subject to a budget constraint:

$$
P_{t} C_{t}+P_{t} q_{t} K_{t+1}+B_{t}=W_{t} L_{t}+P_{t} r_{t}^{K} K_{t}+\left(1+r_{t-1}\right) B_{t-1}+P_{t} T_{t},
$$

where $C_{t}$ is real consumption, $B_{t}$ are nominal bonds issued by the government, $L_{t}$ is labour supply, $K_{t}$ is the real capital stock, and $T_{t}$ are real lump sum transfers received by the household (net lump-sum transfers or taxes from the government, profits from the monopolistically competitive firms owned by the household, and net returns from banking and entrepreneurial activities). $P_{t}$ is the price index, $q_{t}$ is the real value of capital, $W_{t}$ is the nominal wage rate, $r_{t}^{K}$ is the real rental rate of capital, and $r_{t}$ is the nominal short-term interest rate.

I specify a standard CES utility function for the household:

$$
U\left(C_{t}, L_{t}\right)=Z_{t}^{c} \frac{C_{t}^{1-\sigma}}{1-\sigma}-\frac{\chi L_{t}^{1+\theta}}{1+\theta} .
$$

Here $\sigma>0$ is the risk aversion parameter, $\theta>0$ is the inverse of the Frisch elasticity of labour subsitution, and $\chi>0$ is the labour disutility coefficient. $Z_{t}^{c}$ is an exogenous preference shock, which captures real demandside disturbances.

This household problem leads to the following optimality condition for labour supply and two Euler equations for bond and capital holdings:

$$
\begin{aligned}
w_{t} & =-\frac{U_{L}\left(C_{t}, L_{t}\right)}{U_{C}\left(C_{t}, L_{t}\right)} \\
1 & =\beta E_{t}\left[\lambda_{t, t+1}\left(1+r_{t}\right) \frac{P_{t}}{P_{t+1}}\right] \\
q_{t} & =\beta E_{t}\left[\lambda_{t, t+1}\left(r_{t+1}^{K}+(1-\delta) q_{t+1}\right)\right],
\end{aligned}
$$

where $\lambda_{t, t+1}=\frac{U_{C}\left(C_{t+1}, L_{t+1}\right)}{U_{C}\left(C_{t}, L_{t}\right)}$ is the marginal rate of intertemporal substitution, and $w_{t}=\frac{W_{t}}{P_{t}}$ is the real wage.

The parameter $\beta \in(0,1)$ denotes the discount factor of the household, $\sigma$ is the elasticity of consumption, $\phi$ is the Frisch elasticity of labour supply, and $\chi>0$ is a scaling factor for the disutility of labour supply. 


\subsection{Final good production}

Final good producers bundle the intermediate goods $Y_{t}(i)$ into final goods $Y_{t}$ using a standard aggregation technology

$$
Y_{t}=\left(\int_{0}^{1} Y_{t}(i)^{\frac{\varepsilon-1}{\varepsilon}} d i\right)^{\frac{\varepsilon}{\varepsilon-1}}, \quad \varepsilon>0 .
$$

There is free entry and exit in the final good sector, and the firms are perfectly competitive.

The maximisation problem of the final good producers, combined with the zero-profit condition, yields the standard expressions for the demand schedule of intermediate good $Y_{t}(i)$ and the aggregate price level $P_{t}$ :

$$
\begin{aligned}
Y_{t}(i) & =\left(\frac{P_{t}(i)}{P_{t}}\right)^{-\varepsilon} Y_{t} \\
P_{t} & =\left(\int_{0}^{1} P_{t}(i)^{1-\varepsilon} d i\right)^{\frac{1}{1-\varepsilon}}
\end{aligned}
$$

\subsection{Intermediate good production}

There is a continuum of intermediate good producers of mass one, indexed by $i$. At the beginning of each period, the intermediate firm $i$ rents capital $K_{t}(i)$ from the household at price $r_{t}^{K}$, and employs labour $L_{t}(i)$ at a nominal wage rate $W_{t}$.

Each intermediate firm uses a Cobb-Douglas production technology

$$
Y_{t}(i)=Z_{t} K_{t}(i)^{\alpha}\left(L_{t}(i)\right)^{1-\alpha}
$$

where $Z_{t}$ is an exogenous total factor productivity shock.

Cost minimisation by the intermediate firm yields the standard optimality conditions for the capital and labour demand given the relative factor prices, 
and a condition for the real marginal cost $\psi_{t}$ :

$$
\begin{aligned}
\frac{r_{t}^{K}}{w_{t}} & =\frac{\alpha L_{t}(i)}{(1-\alpha) K_{t}(i)}, \\
\psi_{t} & =\left(\frac{r_{t}^{K}}{\alpha}\right)^{\alpha}\left(\frac{w_{t}}{1-\alpha}\right)^{(1-\alpha)} Z_{t}^{-1} .
\end{aligned}
$$

Each firm is able to set its price in a staggered manner à la Calvo (1983). In any given period, the constant probability of being able to reset the price is $1-\omega$, with $0<\omega<1$. The profit maximisation problem of the intermediate firm $i$ who is able to reset the price in period $t$ is:

$$
\max _{P_{t}(i)} E_{t}\left[\sum_{k=0}^{\infty} \omega^{k} Q_{t, t+k}\left(\frac{P_{t}(i)}{P_{t+k}}-\Psi_{t+k \mid t}\right) Y_{t+k \mid t}(i)\right],
$$

subject to the demand condition

$$
Y_{t+k \mid t}(i)=\left(\frac{P_{t}(i)}{P_{t+k}}\right)^{-\varepsilon} Y_{t+k}
$$

$Q_{t, t+k}=\beta^{k} \lambda_{t, t+k} \frac{P_{t}}{P_{t+k}}$ denotes the stochastic discount factor that is obtained from the household's optimality conditions. $\Psi_{t}$ denotes the nominal marginal cost.

Focusing on the symmetric equilibrium where all intermediate firms choose the price $P_{t}(i)=P_{t}^{*}$ yields the expression for the optimal price:

$$
P_{t}^{*}=\frac{\varepsilon}{\varepsilon-1} \frac{E_{t} \sum_{k=0}^{\infty} \omega^{k} Q_{t, t+k} \psi_{t+k \mid t} Y_{t+k \mid t} P_{t+k}^{\varepsilon+1}}{E_{t} \sum_{k=0}^{\infty} \omega^{k} Q_{t, t+k} Y_{t+k \mid t} P_{t+k}^{\varepsilon}} .
$$

In this equilibrium, the aggregate price index (8) can be written as:

$$
P_{t}=\left[\omega P_{t-1}^{1-\epsilon}+(1-\omega)\left(P_{t}^{*}\right)^{1-\epsilon}\right]^{\frac{1}{1-\epsilon}},
$$

and the gross inflation rate between periods $t$ and $t-1$ as:

$$
\Pi_{t}=\left[\omega+(1-\omega)\left(\frac{P_{t}^{*}}{P_{t-1}}\right)^{1-\epsilon}\right]^{\frac{1}{1-\epsilon}} .
$$




\subsection{Capital good production}

Capital needed in the production of intermediate good is produced by the entrepreneurs. Entrepreneurs can acquire external funding for the investment projects from banks. The banks, on the other hand, invest both their own funds and the deposits of workers into the project. The details of this three-party financing contract are given in the next section. The financial sector is affected by agency costs created by a double moral hazard problem as formulated by Holmström and Tirole (1997) in a partial equilibrium setting.

\subsubsection{The financing contract}

This section describes the partial equilibrium in the financial market. In what follows, small letters denote individual-level variables, whereas capital letters denote aggregate variables.

The financial sector consists of banks that channel funds from the workers to the entrepreneurs. Workers can choose to deposit their savings at a bank ${ }^{2}$; to attract deposits, the return on the risky investment has to be high enough for the depositor. In this sense, the deposit is not a safe bank deposit, but rather has to be understood as a short-term risky investment. The deposit and the financing contract are intra-period. ${ }^{3}$ The exact timing of the events is detailed in a later section.

An entrepreneur can borrow money from the bank in order to lever the return to her project. However, she can choose to neglect the investment project to obtain a private benefit. The depositor nor the banker cannot observe whether the project was neglected or not. If the entrepreneur chooses to neglect the project in favour of her private benefit, the productive investment project is less likely to succeed. This presents the first form of moral hazard in the financial sector and creates a friction to the demand side of funds, restricting the ability of the entrepreneur to get external funding for her project.

\footnotetext{
${ }^{2}$ To make the financial sector non-trivial, I assume that a worker cannot deposit his savings in the bank managed by the banker in the same household; nor can the banker lend funds to the entrepreneur in the same household.

${ }^{3}$ This is also why the deposit does not appear in the budget constraint of the household.
} 
In order to mitigate this moral hazard problem, the banker needs to monitor the entrepreneur. But this has a non-verifiable cost to the banker; because of this, he might want to forgo the monitoring. The worker observes whether the project succeeds or not but cannot verify whether the banker properly monitored the entrepreneur. This is the second form of moral hazard in the financial sector, which creates a friction to the supply side of funds. To mitigate this second moral hazard problem, and to be able to attract deposits from the worker, the banker needs to invest some of his own funds to be properly incentivised to monitor the project, i.e., he must have some "skin in the game".

Formally, if $i_{t}$ is the size of an individual investment project, $n_{t}$ is the net worth of the entrepreneur, $a_{t}$ is the net worth of the banker, $\kappa_{t}$ is the unit cost of monitoring the investment project, and $d_{t}$ is the deposit of the worker in period $t$, then:

$$
i_{t}-n_{t} \leq a_{t}+d_{t}-\kappa_{t} i_{t}
$$

gives the maximum amount of external funding an entrepreneur can get for her project, given her own net worth.

A successful project turns $i_{t}$ final goods into $R i_{t}$ capital goods with $R>1$. A failed project yields zero. The one-period contract specifies how the returns of the project are divided between the worker $\left(R_{t}^{w}\right)$, the banker $\left(R_{t}^{b}\right)$ and the entrepreneur $\left(R_{t}^{e}\right)$ :

$$
R \geq R_{t}^{w}+R_{t}^{b}+R_{t}^{e}
$$

There are two types of projects: "good" and "bad" ones (or non-neglected and neglected ones). The project succeeds with probability $p \in\left\{p_{H}, p_{L}\right\}$, with $\Delta p=p_{H}-p_{L}>0$ and $1>p_{H}>p_{L}>0$. If the entrepreneur chooses the good project, the success probability is $p_{H}$, but there is no private benefit to her. There is also a continuum of bad projects, each with the same success probability $p_{L}$, but with an associated positive non-verifiable private benefit $b$ with $0<b \leq \bar{b}$, proportional to the size of the project.

By choosing a monitoring intensity $\kappa_{t} \geq 0$, the banker can prevent the entrepreneur from choosing any of the bad projects with $b \geq b\left(\kappa_{t}\right)$. I assume $b^{\prime}(\kappa) \leq 0, b^{\prime \prime}(\kappa) \geq 0$ and $\lim _{\kappa \rightarrow \infty} b^{\prime}(\kappa)=0$. Because monitoring is costly, it is never possible for the banker to monitor at a level that completely eliminates 
all bad projects.

In order for the three parties to be willing to participate in the contract, the following incentive and participation constraints must be met:

$$
\begin{aligned}
q_{t} p_{H} R_{t}^{w} i_{t} & \geq\left(1+r_{t}\right) d_{t} \\
q_{t} p_{H} R_{t}^{b} i_{t} & \geq\left(1+r_{t}^{a}\right) a_{t} \\
q_{t} p_{H} R_{t}^{b} i_{t}-\kappa_{t} i_{t} & \geq q_{t} p_{L} R_{t}^{b} i_{t} \\
q_{t} p_{H} R_{t}^{e} i_{t} & \geq q_{t} p_{L} R_{t}^{e} i_{t}+b\left(\kappa_{t}\right) i_{t}
\end{aligned}
$$

Equations (16) - (21) define the financial contract. (18) is the participation constraint of the depositor, which tells that the depositor must obtain a gross return at least as high from participating in the project, as she would get on the deposit otherwise; $r_{t}$ is the net outside return on the deposit, which is equal to the short-term market interest rate. Similarly, (19) is the participation constraint of the banker, where $r_{t}^{a}$ is the outside return on bank capital.

(20) and (21) are the incentive constraints of the banker and the entrepreneur, respectively. In order for the banker to be willing to monitor the entrepreneur, the return from the good project, net of monitoring cost, must be at least as much than the return from the bad project. The entrepreneur, in turn, must get at least as much from the good project as she would get from the bad project together with the private benefit.

In equilibrium, all constraints bind. ${ }^{4}$ It is easy to see why: first, the two resource constraints (16) and (17) are trivially binding at optimum. Second, the compensations $R_{t}^{e}$ and $R_{t}^{b}$ must be high enough to properly incentivise the entrepreneur and banker to behave; but by the pie-sharing constraint (17), the more is allocated to them, the less is left for the depositor, who is the residual claimant of the project return. Thus, the depositor will not participate unless the minimum possible shares that satisfy the incentive and participation constraints are allocated to the entrepreneur and the banker.

As a consequence, in each period, the entrepreneur and the banker invest their whole net worth (net of monitoring cost), as well as the whole deposit

\footnotetext{
${ }^{4}$ See Holmström and Tirole (1997) for a detailed discussion.
} 
of the worker, into the investment project, and the entrepreneur always undertakes the good project.

In order to guarantee that the good investment project is desirable compared to the bad projects from the household's point of view, I further assume that $q_{t} p_{H} R>\max \left\{1+r_{t}, q_{t} p_{L} R+\bar{b}\right\}$. This assumption also guarantees that the project has a positive rate of return (and positive pledgeable income).

\subsubsection{Optimal investment and leverage}

In this section, I solve for the optimal leverage ratio of the entrepreneur, and the corresponding optimal size $i_{t}$ of an investment project. From the incentive constraints (20) and (21), the banker and the entrepreneur must get at least

$$
\begin{aligned}
R_{t}^{b} & =\frac{\kappa_{t}}{q_{t} \Delta p} \\
R_{t}^{e} & =\frac{b\left(\kappa_{t}\right)}{q_{t} \Delta p}
\end{aligned}
$$

to be properly incentivised in equilibrium. In other words, the more severe the moral hazard of the entrepreneur at any given monitoring level, the more she must be compensated for undertaking the good project instead of the bad one; and the costlier monitoring is, the more the banker has to be compensated.

The depositor is the residual claimant of the return, who can then get at most

$$
R_{t}^{w}=R-R_{t}^{b}-R_{t}^{e}=R-\frac{b\left(\kappa_{t}\right)+\kappa_{t}}{q_{t} \Delta p} .
$$

Therefore it is in the best interest of the depositor that the project is properly monitored to guarantee that the good project is chosen. In equilibrium, the entrepreneur and the banker get the minimum return that satisfies their incentive constraints, and the depositor gets the maximum residual return. 
From the participation constraints (18) and (19) it follows:

$$
\begin{aligned}
R_{t}^{w} & =\frac{\left(1+r_{t}\right) d_{t}}{q_{t} p_{H} i_{t}} \\
R_{t}^{b} & =\frac{\left(1+r_{t}^{a}\right) a_{t}}{q_{t} p_{H} i t} .
\end{aligned}
$$

Combining (22) with (26) yields:

$$
\frac{a_{t}}{i_{t}}=\frac{p_{H}}{\Delta p} \frac{\kappa_{t}}{1+r_{t}^{a}} .
$$

Further, combining (24) with (25) yields:

$$
\frac{d_{t}}{i_{t}}=\frac{q_{t} p_{H} R}{1+r_{t}}-\frac{p_{H}}{\Delta p} \frac{\kappa_{t}+b\left(\kappa_{t}\right)}{1+r_{t}} .
$$

Equations (27) and (28) indicate that the greater is the cost of monitoring, $\kappa_{t}$, the less deposits can be attracted from the worker, as the worker cannot be convinced as easily that the project is properly monitored. The amount of deposits is also decreasing in the severity of the moral hazard, $b\left(\kappa_{t}\right)$. On the other hand, it is increasing in the total expected return of the project, $q_{t} p_{H} R$.

Substituting (27) and (28) into the resource constraint (16) gives, after some manipulation, the optimal investment as a function of the inverse leverage $g_{t}$ :

$$
i_{t}=\frac{n_{t}}{g_{t}},
$$

where the inverse leverage $g_{t} \equiv g\left(r_{t}, r_{t}^{a}, q_{t}, \kappa_{t}\right)$ is given by:

$$
g_{t}=1-\frac{q_{t} p_{H} R}{1+r_{t}}+\frac{p_{H}}{\Delta p} \frac{b\left(\kappa_{t}\right)}{1+r_{t}}+\left(1+\frac{p_{H}}{\Delta p}\left(\frac{1}{1+r_{t}}-\frac{1}{1+r_{t}^{a}}\right)\right) \kappa_{t} .
$$

Notice that $\frac{q_{t} p_{H} R}{1+r_{t}}-1 \equiv \rho_{t}$ is the net pledgeable income of the project, i.e. maximum net excess return that the entrepreneur can promise to the investors. Equation (30) tells that the worse the moral hazard of the entrepreneur, the costlier monitoring, the smaller the net pledgeable income, or the lower the real value of capital $q_{t}$ is, the less the entrepreneur can attract external funding (or lever the investment size).

Now, the problem of the entrepreneur is to choose $i_{t}$ to maximise her ex- 
pected profit, given her net worth $n_{t}$ and the inverse leverage $g_{t}$. As the profits are proportional to the investment size, expected profit is maximised when $i_{t}$ is maximised, or in other words, when the leverage ratio $\frac{1}{g_{t}}$ is maximised. Given prices, $g_{t}$ is fully determined by the monitoring intensity $\kappa_{t}$.

Let $\kappa_{t}^{*}$ denote the monitoring intensity that maximises the entrepreneurs profit. Using (21) and (29), the entrepreneur's expected profit in terms of $\kappa_{t}^{*}$ can be expressed as (taking as given the prices $q_{t}, r_{t}$ and $r_{t}^{a}$ ):

$$
q_{t} p_{H} R_{t}^{e} i_{t}=\frac{p_{H}}{\Delta p} \frac{b\left(\kappa_{t}^{*}\right) n_{t}}{g\left(\kappa_{t}^{*}\right)}
$$

Thus, the monitoring intensity that maximises the entrepreneur's profit is found by solving:

$$
\kappa_{t}^{*}=\underset{\kappa_{t}}{\arg \max } \frac{b\left(\kappa_{t}\right)}{g\left(\kappa_{t}\right)} .
$$

In order to solve this problem, let us assume the following functional relationship between the monitoring intensity and the size of the private benefit:

$$
b\left(\kappa_{t}\right)= \begin{cases}\Gamma \kappa_{t}^{-\frac{\gamma}{1-\gamma}} & \text { if } \kappa_{t}>\underline{\kappa} \\ \bar{b} & \text { if } \kappa_{t} \leq \underline{\kappa} .\end{cases}
$$

where $0<\gamma<1, \Gamma>0, \bar{b}>0$. In other words, there is a lower bound $\underline{\kappa}$ for the efficiency of monitoring under which the maximum private benefit is always feasible. When $\kappa_{t}>\underline{\kappa}$, the amount of private benefit is a strictly convex function of the monitoring intensity, increasing in $\Gamma$, and decreasing in $\gamma$.

This specification of the monitoring technology yields the following interior solution to the problem (32):

$$
\kappa_{t}^{*}=\frac{\gamma \rho_{t}}{1+\frac{p_{H}}{\Delta p}\left(\frac{1}{1+r_{t}}-\frac{1}{1+r_{t}^{a}}\right)},
$$

which, when substituted into equation (30), yields the following equilibrium degree of inverse leverage:

$$
g\left(\kappa_{t}^{*}\right)=\frac{p_{H}}{\Delta p} \frac{b\left(\kappa_{t}^{*}\right)}{1+r_{t}}-(1-\gamma) \rho_{t},
$$


which in turn determines the equilibrium investment size.

The endogenous monitoring intensity $\kappa_{t}^{*}$ plays a key role in the dynamics of the financial sector. If $\kappa_{t}^{*}$ were constant, the monitoring intensity would not react to any disturbances in the economy. Because of this, also the private benefit, and thus the incentives of the entpreneur, would not change. As a result, because the ability of the banker to attract deposits depends on the monitoring of the project, any shock that would reduce the banker's own capital available for investments would just be replaced by increased deposits, and the total amount of loans would not be affected.

In contrast, when $\kappa_{t}^{*}$ is endogenous, it reacts to developments in the financial markets. If the banker's net worth deteriorates, he has less resources to monitor the entrepreneur's project, and thus the moral hazard problem is exacerbated. As a consequence, less deposits can be attracted, and less loanable funds are available. Endogenous monitoring is the key driver behind the financial dynamics of this model, and it is what makes bank capital fundamentally different from entrepreneurial capital or deposits. The aggregate implications of this mechanism are discussed in more detail in Section 5 .

\subsection{Aggregation}

I focus on the symmetric equilibrium where all projects are monitored at the same intensity $\kappa_{t}^{*}$ given by (34), and the capital structure, given by the ratios of own and external funds to total investment $\left(\frac{n_{t}}{i_{t}}, \frac{a_{t}}{i_{t}}\right.$ and $\left.\frac{d_{t}}{i_{t}}\right)$, is equal across entrepreneurs, bankers and depositors, respectively. Notice the size of the project $i_{t}$ may vary.

Then, the corresponding aggregate ratios are simply given by

$$
\frac{N_{t}}{I_{t}}=\frac{n_{t}}{i_{t}}, \quad \frac{A_{t}}{I_{t}}=\frac{a_{t}}{i_{t}}, \quad \frac{D_{t}}{I_{t}}=\frac{d_{t}}{i_{t}},
$$

where capital letters denote aggregate amounts.

The equilibrium aggregate investment in the economy is determined by

$$
\frac{N_{t}}{I_{t}}=g\left(\kappa_{t}^{*}\right),
$$


where $g\left(\kappa_{t}^{*}\right)$ is given by equation (35).

Using the relation (27), the equilibrium rate of return to bank capital is given by

$$
1+r_{t}^{a *}=\frac{1+\gamma \rho_{t} \frac{I_{t}}{A_{t}}}{\left(1+r_{t}\right)^{-1}+\frac{\Delta p}{p_{H}}} .
$$

Next, the laws of motion of the three types of capital are described by the following equations. In equilibrium, the capital stock in the economy evolves according to

$$
K_{t+1}=(1-\delta) K_{t}+p_{H} R I_{t}
$$

Entrepreneurial and bank net worth are defined to evolve according to

$$
\begin{aligned}
& N_{t+1}=\lambda^{e}\left(1+r_{t}^{e}\right) \frac{r_{t+1}^{K}+(1-\delta) q_{t+1}}{q_{t}} N_{t} \\
& A_{t+1}=Z_{t}^{b} \lambda^{b}\left(1+r_{t}^{a}\right) \frac{r_{t+1}^{K}+\left(1-\delta_{t}\right) q_{t+1}}{q_{t}} A_{t},
\end{aligned}
$$

where $r_{t+1}^{K}+(1-\delta) q_{t+1}$ is the marginal value of a unit of capital in period $t+1$, which is composed of two parts: the rental income at the beginning of the period $r_{t+1}^{K}$, and the value of undepreciated capital $(1-\delta) q_{t+1}$ remaining at the end of the period. ${ }^{5} \lambda^{e}$ and $\lambda^{b}$ are the fractions of entrepreneurs and bankers, respectively, surviving from period $t$ to $t+1$. The return to entrepreneurial capital is simply defined as $1+r_{t}^{e} \equiv \frac{q_{t} p_{H} R_{t}^{e} I_{t}}{N_{t}}$, which is the ratio of expected profit to net worth.

To introduce a shock arising in the financial market into the model, I let the accumulation of bank capital be affected by an aggregate shock, $Z_{t}^{b}$. I assume $Z_{t}^{b}$ is an $\operatorname{AR}(1)$ process with a normally distributed i.i.d. innovation term. A negative shock to $Z_{t}^{b}$ corresponds to an exogenous and unanticipated decrease in the accumulation of bank capital, or in other words, a sudden erosion of bank net worth, common to the whole banking sector. The shock hinders the banks' ability to extend funding to entrepreneurs, and could lead to a credit crunch if severe enough.

Finally, by using the demand schedule (7) and the production technology

\footnotetext{
${ }^{5}$ Recall that the proceeds of the investment project, $R i_{t}$, are paid in capital goods.
} 
(9), the aggregate production is:

$$
Y_{t}=Z_{t} K_{t}^{\alpha} L_{t}^{1-\alpha}
$$

The aggregate consistency constraint of the economy is:

$$
Y_{t}=\left(C_{t}+I_{t}\right) s_{t},
$$

where $C_{t}$ denotes aggregate private consumption and $I_{t}$ aggregate investment. ${ }^{6}$ Finally, $s_{t}=(1-\omega)\left(\frac{P_{t}^{*}}{P_{t}}\right)^{-\varepsilon}+\omega \Pi_{t}^{\varepsilon} s_{t+1} \geq 1$ is the resource cost caused by the price dispersion.

To close the model, a monetary policy for setting the nominal interest rate $r_{t}$ needs to be specified. A macroprudential policy for dealing with the agency cost in financial intermediation is not needed to close the model, but it is required to approximate an efficient equilibrium of the model.

I start by analysing the constrained optimal policies under a social planner's solution in Section 4.3. Then, I look at simple policy rules that can be used to approximate the constrained optimum, detailed in Section 5.3. The policy rules consist of a Taylor-type rule for monetary policy, and a similar rule for macroprudential policy that aims are mitigating the moral hazard problem in the financial sector.

\subsection{Equilibrium}

The competitive equilibrium of the economy is a time path

$$
\left\{C_{t}, K_{t}, L_{t}, I_{t}, A_{t}, N_{t}, D_{t}, q_{t}, r_{t}^{K}, r_{t}, \bar{r}_{t}^{a *}, \bar{r}_{t}^{e}, w_{t}, \psi_{t}, P_{t}, P_{t}^{*}, R_{t}^{b}, R_{t}^{e}, R_{t}^{w}, \bar{\kappa}_{t}^{*}, \tau_{t}\right\}_{t=0}^{\infty}
$$

that satisfies the households' problem, the final and intermediate firms' problems, the optimal financing contract, and the aggregate consistency condition. The equilibrium dynamics as well as the deterministic steady state equilibrium of the model economy are summarised in Appendix B.

\footnotetext{
${ }^{6}$ I assume that the monitoring of investment projects does not consume real resources. If it did, the resource constraint would be $Y_{t}=C_{t}+\left(1+\kappa_{t}^{*}\right) I_{t}$. This assumption is not restrictive, as $\kappa_{t}^{*}$ is very small in equilibrium, and it facilitates the computation of the steady state of the model.
} 
The production phase

- Households rent capital $K_{t}$ and supply labour $L_{t}$ to intermediate firms.

- The aggregate productivity shock $Z_{t}$ is realised; intermediate and final production take place.

The consumption and investment phase

- Entrepreneurs acquire funding for new investment projects. The financing contract is agreed upon, given $N_{t}$ and $A_{t}$.

- Monitoring and realisation of the investment projects take place.

- The outcome of the project is observed. Returns to investment are distributed according to the contract.

- The aggregate financial shock $Z_{t}^{b}$ is realised. Entrepreneurs and bankers accumulate net worth

- $N_{t+1}$ and $A_{t+1}$. Exiting bankers and entrepreneurs transfer their accumulated wealth to their household.

- The demand shock $Z_{t}^{c}$ is realised. Consumption and saving decisions take place.

Table 1: Timing of events

\subsection{Timing of events}

The timing of the events is as follows. Each time period is divided into two phases, described in Table 1.

\section{Calibration}

The calibration of the model largely follows the calibration strategy discussed in Haavio et al. (2015). Assuming that a steady state investment subsidy is in place, so that steady state investments are at the efficient level, the steady state of the New Keynesian macro block is not affected by the parameters of the financial sector. Thus the macro and the financial block can be calibrated independently.

The macro block of the model is calibrated in a standard fashion in the NewKeynesian literature to match a quarterly frequency in data, in order for the model to be easily comparable to a benchmark New Keynesian model without financial frictions. The parameter values are summarised in the upper panel of Table 2. 


\begin{tabular}{|c|c|c|}
\hline \multicolumn{3}{|l|}{ Panel 1: New Keynesian block } \\
\hline Discount factor & $\beta$ & 0.9951 \\
\hline Risk aversion & $\sigma$ & 2 \\
\hline Habit persistence & $b$ & 0 \\
\hline Capital depreciation rate & $\delta$ & 0.025 \\
\hline Elasticity of substitution (mark-up: $10 \%$ ) & $\epsilon$ & 11 \\
\hline Capital share & $\alpha$ & 0.33 \\
\hline Frisch elasticity of labour supply & $\theta$ & 0.5 \\
\hline Disutility of labour supply & $\xi$ & 2 \\
\hline Calvo parameter & $\omega$ & 0.8 \\
\hline Persistence of productivity shock & $\rho$ & 0.95 \\
\hline Persistence of preference shock & $\rho_{c}$ & 0.7 \\
\hline Std. dev. of productivity shock & $\sigma_{\epsilon}$ & 0.006 \\
\hline Std. dev. of preference shock & $\sigma_{c}$ & 0.005 \\
\hline \multicolumn{3}{|l|}{ Panel 2: Financial block } \\
\hline Elasticity of monitoring & $\gamma$ & 0.2992 \\
\hline Monitoring intensity & $\Gamma$ & 0.0017 \\
\hline Survival rate of entrepreneurs & $\lambda^{e}$ & 0.9842 \\
\hline Survival rate of bankers & $\lambda^{b}$ & 0.9507 \\
\hline Success probability of good project & $p_{H}$ & 0.95 \\
\hline Gross return of investment project: $R=\frac{1}{p_{H}}$ & $R$ & 1.0526 \\
\hline Probability differential & $\Delta p$ & 0.0454 \\
\hline Persistence of bank capital depreciation shock & $\rho_{b}$ & 0 \\
\hline Std. dev. of bank capital depreciation shock & $\sigma_{b}$ & 0.006 \\
\hline
\end{tabular}

Table 2: Benchmark calibration of the model 
The financial block is calibrated to match some steady state characteristics of the model. The entrepreneur and banker survival rates, $\lambda^{e}$ and $\lambda^{b}$ respectively, are calibrated to match a steady state excess return on entrepreneurial capital of $4.5 \%$ and an excess return on (core) private bank capital of $20 \%$ per annum, compared to the short-term market interest rate. These values are consistent with the the estimates in Albertazzi and Gambacorta (2009).

The calibration of the monitoring parameters $\gamma$ and $\Gamma$ pin down the monitoring cost in the steady state, and also steady state leverage, because the steady state entrepreneur leverage is fully determined by the monitoring intensity. On the other hand, also bank leverage depends on the monitoring intensity, as it determines its ability to attract deposits. Hence, these two parameters are the key parameters governing the financial sector dynamics.

The exact cost of monitoring activities in banks is hard to pin down empirically. Banks' overheard costs as a fraction of total assets in the U.S. are estimated to be around $3 \%$ by the World Bank (2013). Overhead costs, however, include also costs not related to monitoring activities. Philippon (2014) estimates that the unit cost of financial intermediation has been stable at around $1.5 \%$ to $2 \%$ in the U.S. over the past decades. The calibration of $\gamma$ and $\Gamma$ matches a per annum monitoring cost of $1.2 \%$ of total bank assets in steady state.

The leverage of non-financial U.S. firms is estimated to be around 2.3-2.5 by Kalemli-Ozcan et al. (2011). They also find that leverage ratios of financial firms are very heterogenous in the U.S. and depend on the type of the bank. Large investment banks have leverage ratios in the order of 20, while commercial banks typically have leverage ratios ranging around 10-12. The elasticity of monitoring and monitoring intensity are calibrated in such a way as to produce a leverage ratio of around 1.5 for non-financial firms (entrepreneurs, in this model), and a leverage ratio of 16.5 for banks.

The success probability of the good project and the gross return from the project, $p_{H}$ and $R$, are normalised such that $p_{H} R=1$, which makes the evolution of the aggregate capital accumulation comparable to the standard New Keynesian case. I set $p_{H}=0.95$, which implies a net return $R-1$ on the investment project equal to approximately $5 \%$.

Finally, the financial shock is calibrated to be purly transitory at $\phi_{b}=0$. 
The standard deviance of the shock is calibrated to be the same than that of the productivity shock. The parameters of such a financial shock is hard to pin down empirically, but the calibration is intended to represent the financial shock as a strong but brief event on the financial markets. Given that it takes time for banks hit by the shock to rebuild their capital stock, the transitory shock has persistent effects.

\section{The constrained optimum}

This section discusses the implications of the agency problem in financial intermediation, and analyses the constrained optimal solution under both flexible and sticky prices, when the moral hazard problem is nonetheless present. Optimal policy responses of the Ramsey planner are presented through impulse response analysis, and the efficiency of the optimum is discussed. The efficient first-best optimum, to which the constrained optimal solutions are compared, is the equilibrium of the standard flexible price real business cycle (RBC) model without any friction in financial intermediation. It turns out that if the model economy suffers from both a nominal and a financial friction, the Ramsey planner needs two separate instruments to reach an efficient optimum. After the optimal policy analysis, I will compare the results to dynamics under non-optimised simple policy rules in the next section.

\subsection{Implications of the financial friction}

In addition to the nominal friction arising from staggered price setting, and the inefficiency caused by monopolistic competition in intermediate good production, there is an additional real friction compared to the standard New Keynesian model: the friction arising from the agency costs in the financial sector.

Let us focus on the flexible price model (where $\omega=0$ ). If $b\left(\kappa_{t}\right)=0$, i.e. there are no private benefits available for the entrepreneur, and consequently, no need for monitoring $\left(\kappa_{t}=0\right)$, the incentive constraints (20) and (21) always hold: there is no incentive problem. 
Then, the entrepreneur and the banker are indifferent between undertaking the good project and not when $R_{t}^{e}=R_{t}^{b}=0$. The depositor-worker receives the whole gross return, $R_{t}^{w}=R$. In this case, the financial intermediation becomes "invisible" in the sense that it is as if the worker himself would directly undertake the project, i.e. the household becomes a capital producer. This is in essence equal to the standard flexible price RBC model, where the household's savings are directly channelled into productive investment. As a consequence, aggregate investment equals household savings in equilibrium: $I_{t}=D_{t}$. The RBC model is thus nested within the model presented in this paper, and makes comparison with the dynamics of the standard model straightforward.

Frictions in the financial market cause aggregate investments to be at a suboptimal level. When these frictions are present, aggregate investments $I_{t}$ depend on the total amount of entrepreneurial and bank capital, $N_{t}$ and $A_{t}$, and - through their effect on leverage - on the size of private benefits $b\left(\kappa_{t}\right)$ and the monitoring intensity $\kappa_{t}$. The more severe the incentive prob-

lems, the less funds can be channelled into the investment projects. The inefficiency of credit intermediation is exacerbated by the monitoring cost: because of it, less resources are available for productive investments. Both the entrepreneurs and the bankers are capital-constrained.

\subsection{Constrained optimum in a flexible price economy}

This section and the following sections present the model dynamics under Ramsey-optimal policy plans. The Ramsey policy problem consists of maximising the household's lifetime welfare (1) conditional on the non-linear equilibrium conditions of the private sector in the model economy. I then approximate the optimality conditions of the Ramsey problem by a firstorder Taylor approximation in logs around the deterministic steady state of the model. The choice variables of the Ramsey planner in this setup are either the inflation rate, or both the inflation rate and the level of investments; the planner is assumed to be able to set the values of these variables directly. The Ramsey planner is assumed to act under commitment.

I discuss the responses of the approximated model to various shocks through impulse response analysis. All figures presented in the following sections 
show the resulting dynamics as percentage deviations from steady state values.

An efficient allocation requires that investments be at the level determined by a perfectly competitive and frictionless economy. Let us for a moment drop the assumptions of monopolistic competition and sticky prices, and concentrate on the model where prices are fully flexible and intermediate good production is perfectly competitive, but the moral hazard problem in financial intermediation is present. The government can replicate the efficient steady-state allocation by introducing a constant investment subsidy that restores the efficient amount of investment. In the analysis presented in the following sections, it is assumed that such a subsidy is in place; see Appendix B. 2 for details.

In order to analyse the constrained optimal dynamic equilibrium, I look at a social planner's problem. The Ramsey policy problem of a social planner is described in technical detail in Appendix C. Assume that the planner cannot remove the moral hazard problem (i.e cannot make $b\left(\kappa_{t}\right)=0$ feasible for any value of $\kappa_{t}$ ), but can set the level of investments directly to the value that maximises household welfare ${ }^{7}$. This Ramsey policy problem leads to the constrained optimal equilibrium.

The constrained optimum is defined as being efficient when it replicates the flexible price perfect competition outcome, which is the first-best outcome. In the flexible price economy where the financial friction is present, the fluctuation of the real price of capital $\left(q_{t}\right)$ away from unity creates a wedge between the first-best and the actual outcome. The value of Tobin's $q$ fixed at unity is a key feature of the flexible price RBC model, which follows from the frictionless adjustment of capital. In order to replicate the first-best, the Ramsey planner thus needs to offset this wedge.

Figure 1 shows the response of the economy to a one-standard-deviation negative productivity shock. The figure illustrates that the constrained optimal solution of the social planner is efficient: the allocation replicates the first-best (unconstrained) optimum, which in this case is the flexible price frictionless outcome, denoted by the solid black line in the figure. The solid

\footnotetext{
${ }^{7}$ This policy can be thought of as a set of transfers in each period between the entrepreneurs, the bankers and the depositors that reallocates wealth in a way to achieve the optimal level of investments
} 

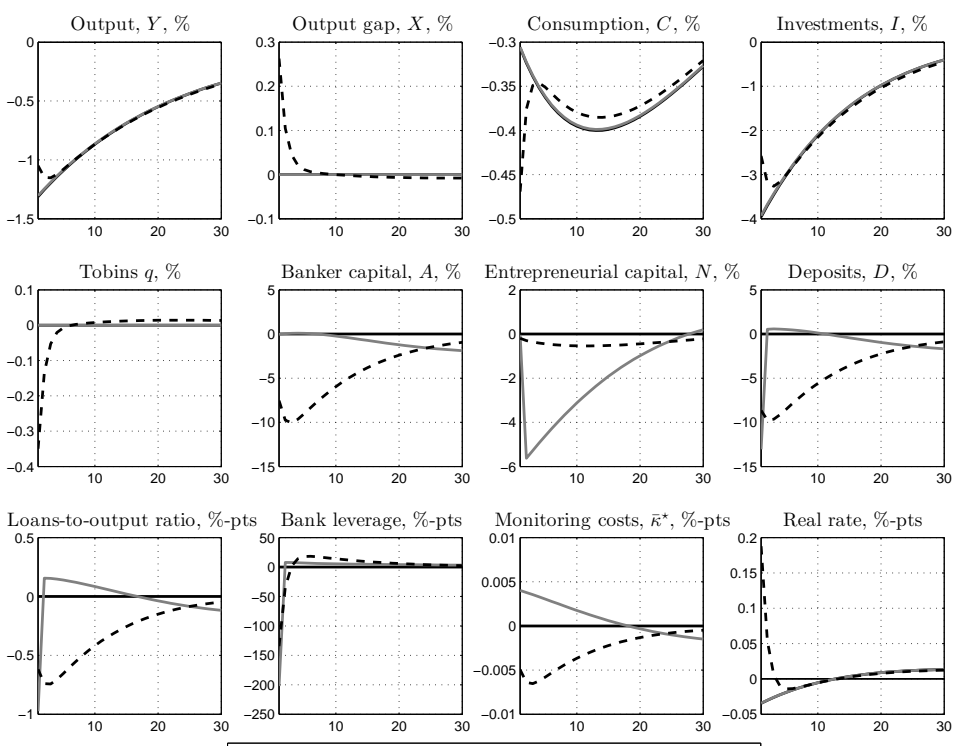

Figure 1: Effects of a one percent negative total factor productivity shock in the RBC model. "Flexible price RBC": model with fully flexible prices and no financial friction. "Constrained-optimal RBC": model with fully flexible prices, but with the financial friction. "No intervention": model with fully flexible prices, but with the financial friction; no policy intervention.

grey line denotes the response in the economy with financial frictions when a social planner intervenes by implementing the Ramsey policy, and the dashed line indicates the response of the economy with financial frictions and no policy intervention.

The output gap $X_{t}$ is defined as the gap between actual output in a given model and the output in the flexible price RBC model: $X_{t}=\frac{Y_{t}}{Y_{t}^{e}}$, where $Y_{t}$ is the actual output and $Y_{t}^{e}$ is the efficient level of output ${ }^{8}$.

The shock increases marginal costs of firms and results in inflationary pressure. Capital demand by intermediate firms decreases, but because of the financial friction - as entrepreneurs attempt to continue undertaking investment projects to keep accumulating wealth - less than in the frictionless $\mathrm{RBC}$ economy. Without any policy intervention, this results in a positive

\footnotetext{
${ }^{8}$ The efficient level of output is a benchmark computed as the output level achievable with the resources of the economy in the absence of monopolistic competition, the pricing friction, and the financial friction.
} 

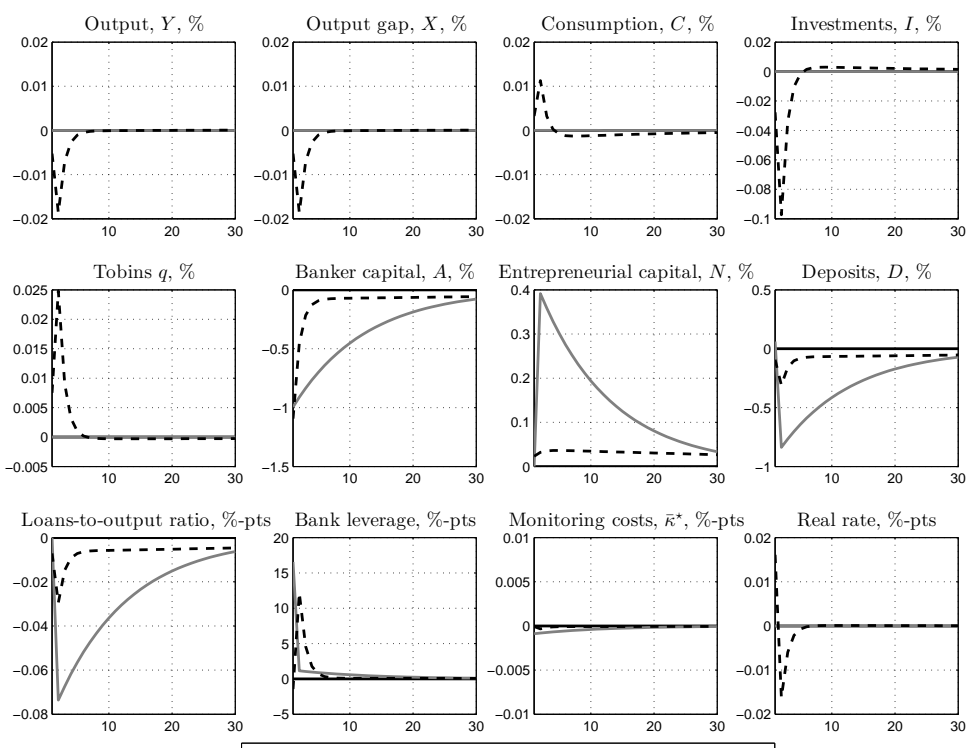

Figure 2: Effects of a one percent negative bank capital shock in the RBC model. "Flexible price RBC": model with fully flexible prices and no financial friction. "Constrained-optimal RBC": model with fully flexible prices, but with the financial friction; policy intervention by the planner. "No intervention": model with fully flexible prices, but with the financial friction; no policy intervention.

output gap as investment does not adjust enough, and in a fall in real capital price $q_{t}$ as a result of the weakened demand for capital.

Instead, with policy intervention, the social planner sets the level of investments to the level that maximises household welfare, given the friction in the financial sector. This corresponds to a re-allocation of resources between the three parties of the financial contract in such a way as to keep the real price of capital, $q_{t}$, fixed at unity. First, the planner transfers resources from the entrepreneur to the banker. This allows the banker to increase the monitoring intensity and attract more deposits. The entrepreneur however has less net worth and can undertake only smaller projects. Thus the demand for loanable funds decreases, which then decreases the supply of new capital in the economy, driving up the capital price $q_{t}$. The stabilisation of Tobin's $q$ allows to replicate the first-best outcome for the aggregate macro variables, specifically the efficient level of investments. 

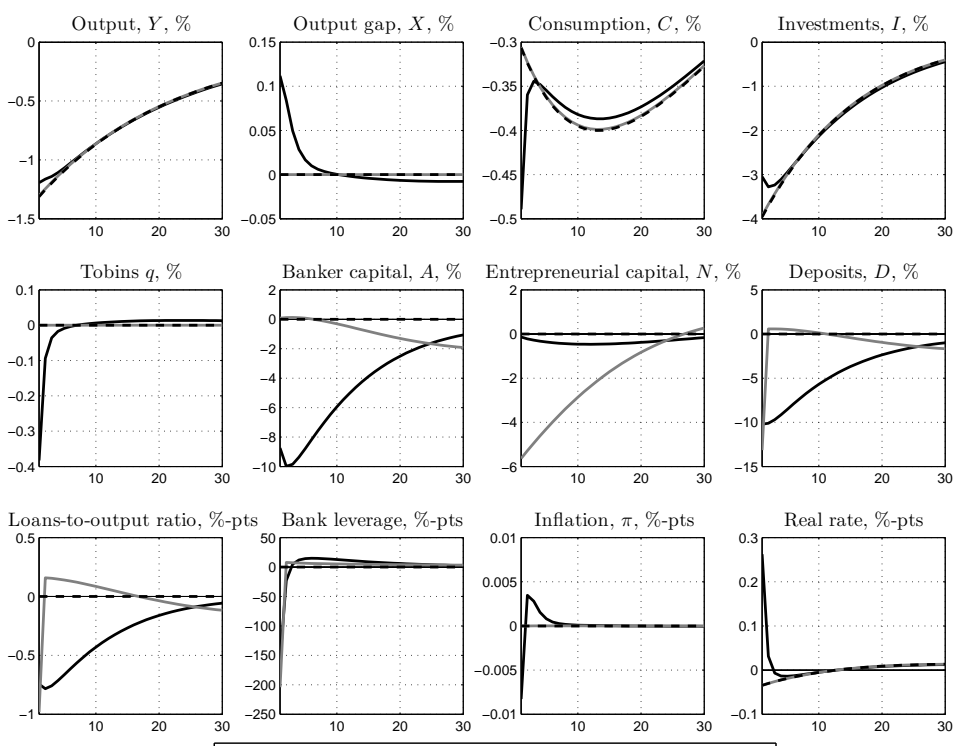

Figure 3: Effects of a one percent negative total factor productivity shock in the New Keynesian model. "Inflation choice": model with sticky prices and the financial friction; social planner sets the inflation rate. "Inflation and investment choice": model with sticky prices and the financial friction; social planner sets the inflation rate and the level of investments. "Flexible price RBC": the frictionless flexible price (first-best) benchmark.

An exactly similar logic applies to stabilising the economy after a negative bank capital shock, shown in Figure 2, and the first-best outcome can again be replicated. In this case, the destruction of bank capital interferes with the banker's ability to extend loans for new projects, such that the supply of new capital decreases and the capital price $q_{t}$ increases, if there is no policy intervention, as shown by the dashed lines. The social planner transfers resources from the depositor and the banker to the entrepreneur, who can then invest in more capital-producing projects without external funding from the market. This pushes down the capital price, as the demand for loans is reduced.

Appendix A reports the corresponding results of a shock to the stochastic discount factor, which is a demand shock. Here, the same conclusion holds: two policy variables are needed to reach the efficient constrained optimum. 


\subsection{Constrained optimum in a sticky price economy}

Next, let us re-introduce the nominal rigidity into the model. Now, besides the financial friction, there are the standard New Keynesian frictions - price stickiness and monopolistic competition in intermediate production - affecting the economy. As was seen in the previous section, the social planner's solution is efficient when prices are fully flexible, but the financial friction is present, when the planner can optimally set the level of investments.

With all of these frictions at work, the planner has to offset fluctuations caused not only by the agency problem, but also those caused by price stickiness and monopolistic competition to achieve efficiency of the constrained optimum. I first look at the case where the planner only has one policy variable that he can set. Namely, the planner controls monetary policy and sets the rate of inflation to maximise household welfare.

The solid lines in Figure 3 show the response of the economy to a negative productivity shock, when the social planner optimally sets the inflation rate. With only one policy variable, the planner cannot fully offset the shock. The planner sets the inflation rate to zero. However, a positive output gap opens up, while at the same time Tobin's $q$ drops. The planner is not able to stabilise both, as the two move in opposite directions. On the one hand, the inflationary pressure caused by the productivity shock would warrant an increase in the nominal interest rate. On the other hand, to push up the capital price, the nominal rate would need to be lowered. The presence of two distinct inefficiencies - sticky prices and the financial friction - create a policy trade-off. The constrained optimum when the planner has only one policy variable is not efficient, as it does not fully replicate the first best outcome (the flexible price RBC equilibrium).

Contrast this result with the standard New Keynesian model, where no financial friction exists: a Ramsey planner can replicate the first-best by fully stabilising inflation, assuming that there is a steady-state employment subsidy in place that offsets the steady state mark-up of the intermediate producers.

In contrast, the dashed lines in Figures 3 show the constrained optimal response when the planner controls two policy variables besides the static employment subsidy: inflation rate and the investment level. Now the first best 

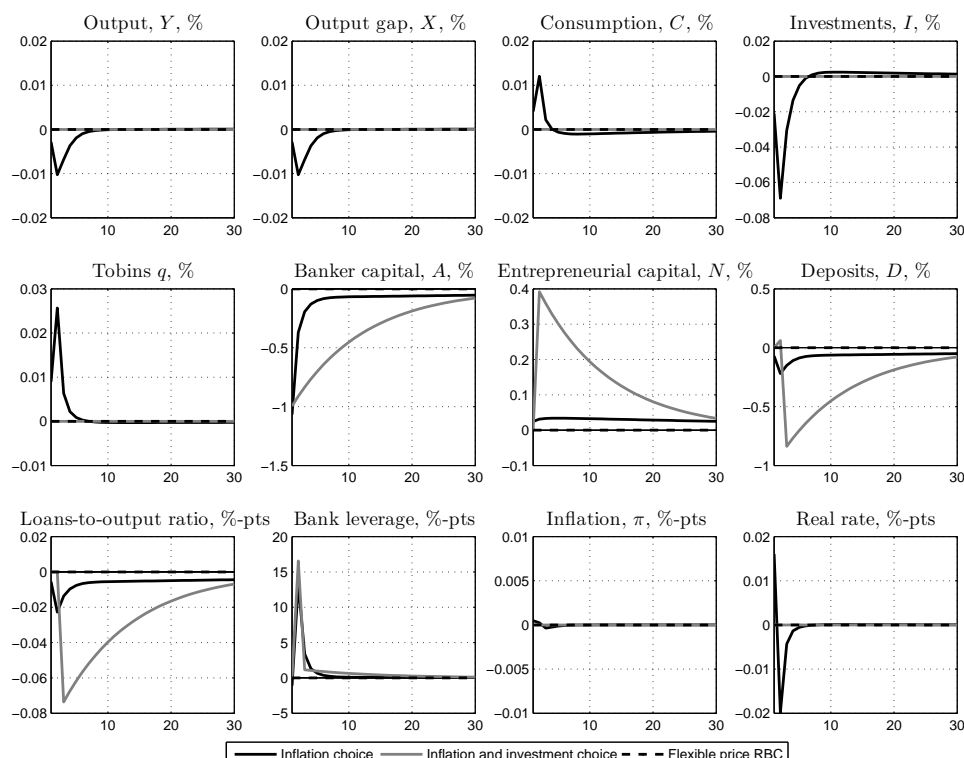

Figure 4: Effects of a one percent negative bank capital shock in the New Keynesian model. "Inflation choice": model with sticky prices and the financial friction; social planner sets the inflation rate. "Inflation and investment choice": model with sticky prices and the financial friction; social planner sets the inflation rate and the level of investments. "Flexible price RBC": the frictionless flexible price (first-best) benchmark.

outcome can be replicated, and the constrained optimum is efficient. One policy variable can be used to offset the distortion caused by price stickiness by stabilising inflation, and the other to offset the distortion in financial intermediation by stabilising Tobin's $q$, so that the policy trade-off is resolved.

The same applies when the economy is hit by a bank capital shock, as depicted in Figure $4 .{ }^{9}$ With only one policy variable, the planner cannot fully offset the shocks. In both cases, Tobin's $q$ and the output gap move in opposite directions, causing a policy trade-off. This trade-off can only be resolved by adding a second policy variable that can deal with the wedge in real capital price.

In particular, after a bank capital shock, when the planner only controls the inflation rate, the deterioration of bank capital causes a drop in investments and leads to a negative output gap. At the same time, the decrease in capital

\footnotetext{
${ }^{9}$ Results for a demand shock are reported in Appendix A.
} 
stock leads to an increase in the real price of capital and causes households to substitute savings for current consumption, which reinforces the drop in investments. In contrast, when the planner can also control the level of investments, the planner can reallocate resources from the depositors and the banks to the entrepreneurs and stabilise Tobin's $q$, as the ability of banks to finance investments is reduced.

\section{Simple policy rules}

The Ramsey policy plans described above represent a constrained optimal solution to setting the monetary and macroprudential policies. The Ramsey policy is, however, a rather abstract policy plan that serves as a benchmark for simpler policy plans and as a tool to help understand how the frictions in the model economy should be dealt with. In particular, the kind of transfers needed in each period to replicate the first-best are likely very hard to implement in a more realistic setting.

From the optimal policy analysis, it becomes clear that the policymaker needs (at least) two separate policy instruments in order to stabilise the economic fluctuations: one to deal with inflation, and one to deal with the financial frictions. A need for separate macroprudential regulation then naturally arises in this context. A way to approximate the Ramsey-optimal transfer plans are dynamic taxes and subsidies on either the entrepreneur or the banker.

In the next sections, I analyse the dynamics of the model economy under various simple policy rules. First, as a benchmark, I look at how the economy performs under a conventional Taylor rule type policy, where the monetary authority reacts to inflation and output gap. This means that there is no macroprudential policy, and the monetary authority is not directly concerned with any financial developments. Then, I consider an augmented Taylor rule, where in addition to inflation and output gap, the central bank also reacts to the real capital price, which in this model is the key channel through which the real economy and the financial markets are linked. Finally, I analyse the dynamics of the model economy where conventional monetary policy is supplemented by an independent macroprudential policy: there is a rulebased policy that deals with financial imbalances, and the central bank only 


\begin{tabular}{lll}
\hline & Policies & Instruments \\
\hline (i) & $\mathrm{MP}$ & Taylor rule \\
(ii) & $\mathrm{MP}+\mathrm{MR}$ & Augmented Taylor rule \\
(iii) & $\mathrm{MP}+\mathrm{MR}$ & Taylor rule + leverage tax \\
(iv) & $\mathrm{MP}+\mathrm{MR}$ & Taylor rule + investment subsidy \\
\hline
\end{tabular}

Table 3: Policy regimes under simple rules. MP: monetary policy; MR: macroprudential policy. Instruments: policy instruments at use.

targets inflation and output gap using a standard Taylor rule.

\subsection{Policy mandates}

As was seen in the previous section, the stabilisation of the economy requires in general two distinct policy tools to deal with the two separate frictions. The key to stabilising the economy, i.e. to close the output gap in order to replicate the first-best flexible price allocation, is to stabilise inflation on the one hand, and Tobin's $q$ on the other hand. A potential trade-off arises, because Tobin's $q$ moves in the opposite direction from the output gap.

The Ramsey policies assume that the policymakers act under commitment, observe all variables in the economy, and can set the instrument values to maximise the household's lifetime welfare. In a more realistic model, the policymakers use simple policy rules, which react to a few key variables. Several possible combinations of policy rules are considered here. I investigate how closely the optimal policy plans can be approximated with these policy rules.

Based on the Ramsey policy analysis, the question arises: what is the most suitable policy mandate - one where the monetary authority jointly deals with both price and financial stability, or one where distinct authorities deal with each friction? The Ramsey planner, by jointly setting both inflation and investments, can replicate the first best. The responses to both inflation and financial imbalances are perfectly coordinated in the sense that they are jointly optimal, and set to maximise the same objective, the household welfare. However, in the absence of such a Ramsey planner, it is not immediately clear what the policy targets should be and how the policy mandates should be divided. 
The simple policy rule set-ups simulate four distinct policy regimes: (i) a regime where only conventional monetary policy that aims at price stability is conducted; (ii) a regime where the monetary authority deals with both price stability and financial stability; and two different regimes where there are two independent policymakers, one for the monetary policy and one for the macroprudential policy, each with their own policy targets: regimes (iii) and (iv), respectively.

The next question is what the specific macroprudential policy should be, if monetary policy is not concerned with financial stability directly as in cases (iii) and (iv) described above. Two specific tools for financial stability are considered: a leverage tax/subsidy on banks, and a tax/subsidy scheme on investment returns of the entrepreneurs. The former restricts bank lending in an expansion and supports it in a recession by controlling their leverage, and thus aims at stabilising credit intermediation. The latter subsidises the returns of the investment projects when they are too low compared to firstbest, i.e. when Tobin's $q$ is below unity and thus stimulates investments, and taxes them when investment demand is too high and Tobin's $q$ is above unity. These policies are detailed in Section 5.2.

The policy regimes are summarised in Table 3. The first column specifies which policies are at use: monetary policy, or both monetary and macroprudential policies. The second column specifies the policy instruments.

Each of these regimes is then compared against the first-best allocation, i.e. the perfect competition flexible price RBC model. In Section 6, I compute welfare measures that further quantify the performance of the different regimes.

The first regime (on the first row of Table 3) consists of a conventional monetary policy rule, which reacts to inflation and output gap. The parameters are chosen to correspond to conventional values in the literature: a weight of 1.5 is given on inflation, and a weight of 0.5 on the output gap. This policy regime consists of one where there is no separate macroprudential policy at all, and conventional monetary policy is assumed to be enough to stabilise the economy.

Next, on the second row of Table 3, the second regime consists of an augmented monetary policy rule. In addition to inflation and output gap with 
the same weight as above, the monetary authority reacts to the real price of capital, or Tobin's $q$, with a weight of unity, so that fluctuations in $q$ are offset one-to-one, other things equal. The price of capital was found to be the key variable to stabilise in order to offset the financial friction and replicate the first-best. This policy regime corresponds to one where the central bank tries to explicitly deal with financial imbalances as well as price stability, but only has one instrument at use. It is a dual mandate, and could be thought of as an approximate counterpart to the Ramsey policy with inflation choice only.

Finally, the third and fourth regime are ones where the tasks of price and financial stability are divided to two different authorities with different policy targets. These are described in the third and fourth rows of Table 3. Monetary policy follows a standard Taylor rule, with the same conventional weights as in the first regime described above. In addition, there is a macroprudential policy that aims at financial stability. I look at two different macroprudential policies. The first is a cyclical leverage tax on banks, which targets the loans-to-output ratio of the economy. When this ratio is above its steady-state level, the tax is positive, so that the banks' aggregate leverage is reduced and lending and thus investment is restricted. When this ratio is below its steady-state level, in a downturn, bank lending is subsidised to stimulate lending.

The second macroprudential policy is a subsidy on investment returns. If Tobin's $q$ is above one, i.e. there is too much investment relative to the first-best, it is a transfer from banks and entrepreneurs to depositors that makes investments less profitable and drives down Tobin's $q$. Conversely, when Tobin's $q$ is below unity and investment is low relative to first-best, it is a subsidy on investments that make them more profitable. This policy aims at stabilising the value of $q$ to unity. 


\begin{tabular}{|c|c|c|c|c|c|}
\hline \multirow[t]{2}{*}{ Regime } & \multicolumn{3}{|c|}{ Taylor rule } & \multirow{2}{*}{$\begin{array}{c}\text { Leverage tax } \\
\phi_{\tau}\end{array}$} & \multirow{2}{*}{$\begin{array}{c}\text { Investment tax } \\
1-\varsigma_{t} \\
\end{array}$} \\
\hline & {$\left[\phi_{\Pi}\right.$} & $\phi_{x}$ & $\left.\phi_{q}\right]$ & & \\
\hline (i) & {$[1.5$} & 0.5 & 0] & 0 & no \\
\hline (ii) & {$[1.5$} & 0.5 & 1] & 0 & no \\
\hline (iii) & {$[1.5$} & 0.5 & 0] & 1 & no \\
\hline (iv) & {$[1.5$} & 0.5 & $0]$ & 0 & yes \\
\hline
\end{tabular}

Table 4: Calibration of policy parameters. Regimes: (i) standard Taylor rule; (ii) augmented Taylor rule; (iii) standard Taylor rule and leverage tax; (iv) standard Taylor rule and investment tax.

\subsection{Monetary and macroprudential policy rules}

\subsubsection{Monetary policy}

First, the central bank sets the nominal short-term interest rate $r_{t}$ using a Taylor rule:

$$
1+r_{t}=\frac{1}{\beta} \Pi_{t}^{\phi_{\pi}} X_{t}^{\phi_{x}} q_{t}^{\phi_{q}}
$$

where $\Pi_{t}$ is the period-to-period gross inflation rate, $X_{t}=\frac{Y_{t}}{Y_{t}^{e}}$ is the output gap, and $q_{t}$ is the real price of capital. The calibration of the policy parameters is given in Table 4. The "standard" Taylor rule refers to a rule which only reacts to inflation and output gap and sets $\phi_{q}$ to zero. The "augmented" Taylor rule refers to a rule which sets $\phi_{q}$ different from zero.

\subsubsection{Macroprudential policy}

I assume that the government follows a balanced budget policy, and that both the leverage tax/subsidy scheme and the investment tax/subsidy scheme is financed by lump sum taxes and transfers on households. This implies that the households' optimal decisions are not affected.

The bank leverage tax

First, the leverage tax on banks, while rather abstract, can under these conditions also be interpreted as a bank resolution fund. The quantitative effects of the tax on banking sector dynamics are similar to capital ratio regulation (as, for example, discussed in Christensen et al. (2011)) but the advantage of the fiscal approach is that unlike a restriction on the capital 
ratio of the bank, the leverage tax does not impose a constraint on the bank's choice of monitoring intensity, and the financing problem remains simple and tractable.

Formally, bank leverage is defined as the ratio of total assets to net worth. Bank net worth is equal to the bank's own capital $a_{t}$, and the total liabilities of the banking sector are composed of bank capital and deposits, $a_{t}+d_{t}$. As an accounting identity, total assets are equal in size to total liabilities. Then, bank leverage can be defined as:

$$
\mathcal{B}=\frac{a_{t}+d_{t}}{a_{t}}
$$

The financial regulator imposes a time-varying tax $\tau_{t}$ on bank leverage, or equivalently, on the bank's total assets. Then, the after-tax net leverage is:

$$
\overline{\mathcal{B}}_{t}=\left(1-\tau_{t}\right) \mathcal{B}_{t}=\left(1-\tau_{t}\right) \frac{a_{t}+d_{t}}{a_{t}} .
$$

When $\tau_{t}>0$, the financial regulator imposes a tax on the bank's total assets that restricts bank leverage. When $\tau_{t}<0$, the regulator subsidizes bank leverage, which stimulates bank lending.

The funding constraint of the bank under this tax is:

$$
i_{t}-n_{t}+\kappa_{t} i_{t} \leq\left(1-\tau_{t}\right)\left(a_{t}+d_{t}\right)
$$

The bank now has to use its own capital and the deposits to finance both the loan to the entrepreneur and the monitoring of the project, as well as to pay for the tax.

The variables net of tax, as well as the aggregate variables, can then be derived exactly as presented in Section 2 .

The financial regulator sets the level of the tax according to a Taylor-type policy rule. The policy target is the credit-to-output ratio $\Upsilon_{t}=\frac{I_{t}-N_{t}}{Y_{t}}$. When this ratio is above its steady state level $\Upsilon=\frac{I-N}{Y}$, i.e. the "credit gap" $\frac{\Upsilon_{t}}{\Upsilon}$ is above unity, the tax rate is positive. When the ratio is below its steady state level, the tax rate is negative, i.e. it is a subsidy to lending. The steady-state level of the tax is set to zero, so that the steady state of the economy is not affected by the distortionary tax/subsidy transfer. 
This choice of target means that the macroprudential policy seeks to restrain the indebtedness of the economy, of which the credit-to-output ratio is a simple measure.

Specifically, the leverage tax is set according to the rule:

$$
1+\tau_{t}=\left(\frac{\Upsilon_{t}}{\Upsilon}\right)^{\phi \Upsilon}
$$

where $\phi_{\Upsilon}$ is the policy parameter defining the intensity of the policy.

\section{The investment tax}

Alternatively, the financial sector can be controlled through a tax and subsidy scheme on the returns of the investment projects. The goal is to stabilise Tobin's $q$ at unity to remove the effects of the agency costs on the level of investments.

On the demand side of loanable funds, the real price of capital is related to the pledgeable income of the investment project through the definition of the pledgeable income:

$$
\begin{aligned}
\rho_{t} & =\frac{q_{t} p_{H} R}{1+r_{t}}-1 \\
\Leftrightarrow \quad q_{t} & =\frac{\left(1+\rho_{t}\right)\left(1+r_{t}\right)}{p_{H} R}
\end{aligned}
$$

Now define $R\left(1-\varsigma_{t}\right)$ as the taxed return on the project when $\varsigma_{t}>0$, and subsidised return when $\varsigma_{t}<0$. Then, the policy objective is to set $\varsigma_{t}$ such that the taxed price of capital $q_{t}^{*}$ is:

$$
q_{t}^{*}=\frac{\left(1+\rho_{t}\right)\left(1+r_{t}\right)}{p_{H} R\left(1-\varsigma_{t}\right)}=1 .
$$

By rearranging and substituting (34) for $\rho_{t}$, the tax that fulfils this condition is:

$$
1-\varsigma_{t}=\left[1+r_{t}+\gamma^{-1} \kappa_{t}^{*}\left(1+r_{t}+\frac{p_{H}}{\Delta p}\left(1-\frac{1+r_{t}}{1+r_{t}^{a}}\right)\right)\right]\left(p_{H} R\right)^{-1} .
$$

This tax transfers a share of the project return from the entrepreneur to the household (the depositor), and vice verse if it is a subsidy. The funding 

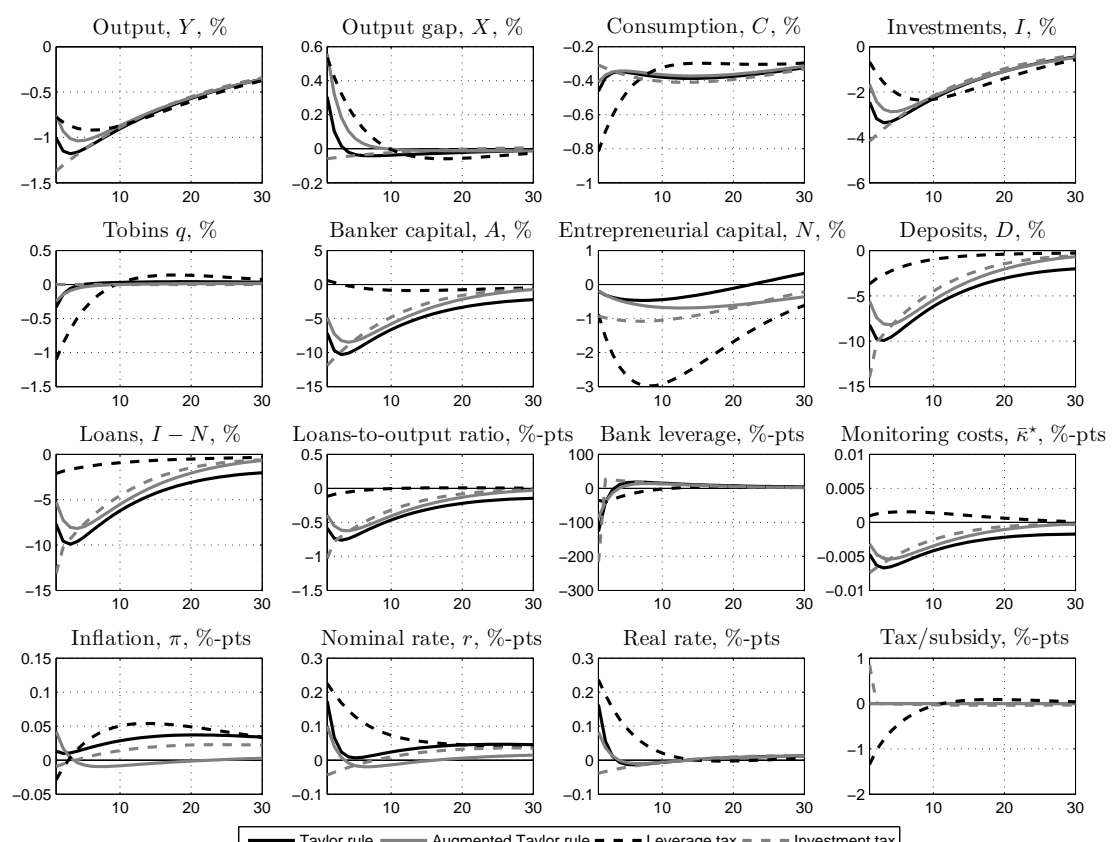

Figure 5: Policy response to a one percent adverse productivity shock. "Taylor rule": the financial frictions model with standard Taylor rule that reacts to inflation and output gap; "Augmented Taylor rule": the financial frictions model with an augmented Taylor rule that reacts to inflation, otuput gap and real capital price; "Leverage tax": the financial frictions model with standard Taylor rule and leverage tax; "Investment tax": the financial frictions model with standard Taylor rule and investment subsidy. "Tax/subsidy" panel: a positive figure indicates a tax, a negative figure a subsidy.

constraint (17) of the financing problem becomes:

$$
R\left(1-\varsigma_{t}\right)=R_{t}^{e}+R_{t}^{b}+R_{t}^{w} .
$$

\subsection{Dynamics under simple policy rules}

Figure 5 shows the policy responses to a negative productivity shock in the economy with financial frictions. The shock is inflationary and produces a positive output gap, so that monetary policy responds by raising the nominal interest rate.

The adverse shock also affects financial intermediation. There is downward 
pressure in investments, which decreases lending. The weakened demand for capital pushes down the real price of capital. When a macroprudential policy is active - in all cases except under the first regime where only a conventional Taylor rule is at use, shown by the solid black lines - it attempts to address this issue.

The augmented Taylor rule, shown in solid grey lines, attempts to offset the fall in real capital price $q$ by raising the interest rate less than when monetary policy does not react to $q_{t}$, but in doing so it allows for a greater output gap, as the two move in opposite directions. The fall in real capital price, however, decreases inflationary pressure.

The investment tax also reacts directly to the downward pressure in $q_{t}$. The policy reactions under this regime are shown in dashed grey lines. By imposing a tax on investment returns, the policy encourages more consumption and less saving by the households, which leads to less supply of funds for investment. This removes the downward pressure from the capital price, and the policy stabilises $q_{t}$ at the desired value of unity. At the same time, the monetary policy is left to take care of the inflation, but the stabilisation of $q_{t}$ removes some of the inflationary pressure, so that monetary policy does not need to react as aggressively as under the other policy regimes.

Finally, the policy regime with a leverage tax, which aims at smoothing out credit cycles by stabilising the loans-to-output ratio, imposes a subsidy on banks' total assets. This policy mix does stabilise financial intermediation, and it is the only policy that leads to improved monitoring resources (and a mitigation of the moral hazard problem). At the same time, however, it prevents investments from adjusting enough to the new productivity levels. As a consequence, both inflation and output gap outcomes are worse than without the tax, and the monetary policy has to counteract the macroprudential policy by raising the nominal interest rate more than it otherwise would have to.

In contrast, when the shock arises in the financial sector, the leverage tax can be helpful. Figure 6 shows the policy responses to a negative shock to bank net worth. Such a shock results in a deterioration of bank capital, which hinders the banks' ability to monitor investment projects. This in turn worsens the moral hazard problem, discourages depositors, and leads 

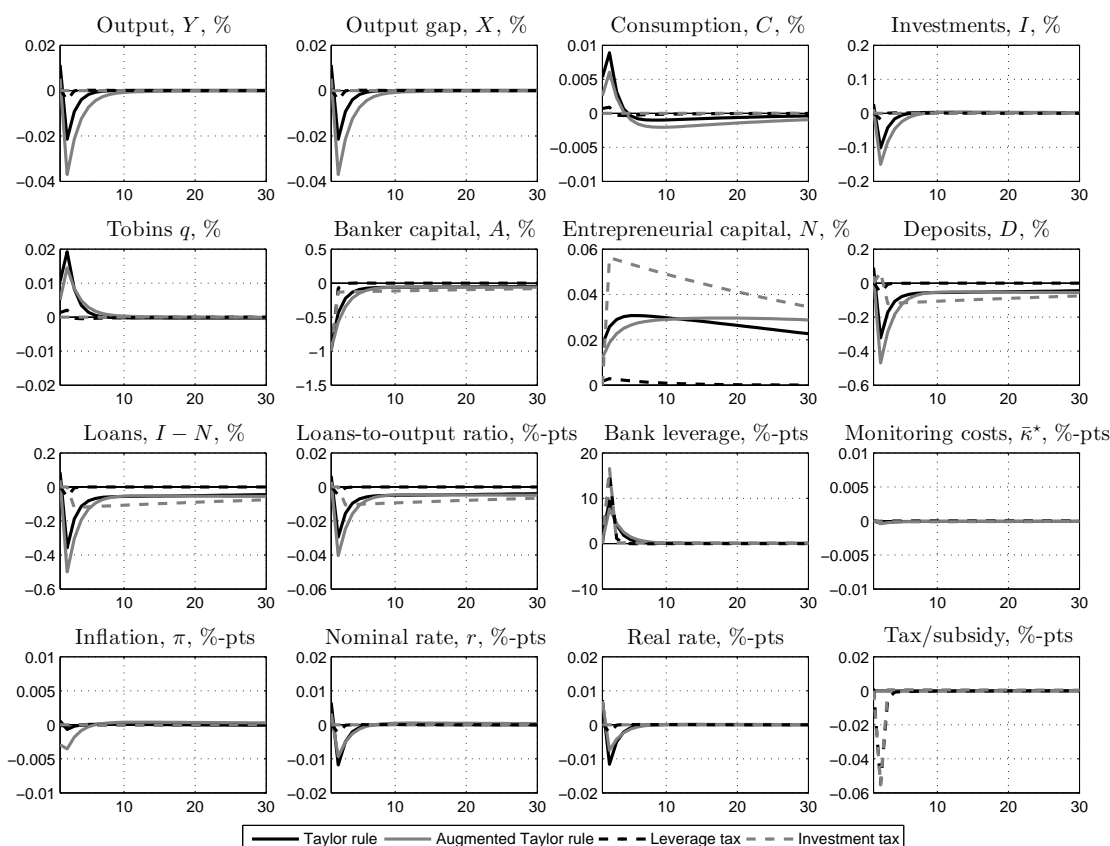

Figure 6: Policy response to a one percent adverse bank capital shock. "Taylor rule": the financial frictions model with standard Taylor rule that reacts to inflation and output gap; "Augmented Taylor rule": the financial frictions model with an augmented Taylor rule that reacts to inflation, otuput gap and real capital price; "Leverage tax": the financial frictions model with standard Taylor rule and leverage tax; "Investment tax": the financial frictions model with standard Taylor rule and investment subsidy. "Tax/subsidy" panel: a positive figure indicates a tax, a negative figure a subsidy. 
to higher requirements of entrepreneurial capital. The decrease in lending translates into decreased investments and output.

However, the shock is also inflationary, because the drop in investments implies an increase in the real price of capital, which in turn encourages households to subsitute savings for consumption. The shock also leads to a persistently lower level of bank capital and lending, because it takes time for banks to re-accumulate net worth.

Now, if the leverage tax is active, the macroprudential policy can support the banks and stabilise credit intermediation, which dampens the effect of the financial shock to real economic activity considerably. In particular, the impact of the shock on inflation is negative, as the shock's effect on the real price of capital is dampened. As the inflationary pressure is removed, monetary policy, supported by macroprudential policy, can instead act on the negative output gap and decrease the interest rate. In addition, bank capital levels are restored much more quickly thanks to the subsidy. In a sense, the policymaker "bails out" banks by providing more capital. The availability of two separate policy tools removes the policy trade-off. The investment subsidy has a similar effect: it increases the profits of the bankers and entrepreneurs from the investment projects, which also stimulates investments and helps banks rebuild their balance sheets.

In turn, the augmented Taylor rule does not perform very well, as it cannot stop the shock from propagating from the financial sector to the real economy as well as a separate macroprudential policy can.

This shows that when there are shocks arising in the financial sector itself, there are benefits to a separate macroprudential tool. However, restricting bank leverage can be counterproductive in stabilising fluctuations caused by shocks arising from outside, but affecting, the financial sector. Controlling investment returns might be a more convenient tool in regulating credit cycles, as it affects the price of investment, not the stock of bank capital available for investment projects. This also highlights the importance of credit intermediation as a channel through which the economy adjusts to real shocks by adapting the level of investments.

When shocks arise from outside of the financial sector but affect financial intermediation, a unified, dual mandate of the monetary authority can be 
beneficial. A coordinated response from one policymaker - here in the form of an augmented Taylor rule, which reacts explicitly both to inflation and real asset prices - seems to yield good results.

These simple examples demonstrate that there is scope for a separate macroprudential tool in dealing with disturbances that arise from the financial sector itself, but also a need to identify the sources of business cycle fluctuations, as well as to properly coordinate the use of monetary and macroprudential policies. The design of the macroprudential policy matters a great deal.

In the next section, I quantify the welfare effects of the different policy regimes. While the quantitative differences in welfare under the different policy regimes are small, the exercise can provide us with an ordering of the regimes in terms of household welfare, compared to the first-best outcome.

\section{Welfare analysis}

In this section, I evaluate the performance of the different policy regimes. I compute the welfare cost associated with each policy as consumptionequivalent amounts relative to a benchmark policy. The welfare evaluation follows the strategy described in Schmitt-Grohé and Uribe (2006). The details of the derivation of the welfare measure are outlined in Appendix D.

The consumption-equivalent welfare cost is defined as the fixed fraction of consumption that the household must give up under the benchmark policy regime, in each period, to be indifferent between the benchmark policy and the policy it is being compared to. A positive cost indicates that the household is better off under the benchmark policy. The benchmark model to which the others are compared here is the flexible price RBC model, which yields the first-best allocation. In the RBC model, both the financial friction and the nominal friction are absent. The details of the computation of the consumption-equivalent welfare measure is given in Appendix D.

The third column of Table 5 reports the welfare costs of the different policy regimes. In addition, the fourth and fifth columns of Table 5 display the standard deviations of inflation and output gap in percentages, respectively, under the different policy regimes. 


\begin{tabular}{llccc}
\hline Model & Policy & Welfare cost $(\%)$ & $100 \times \sigma_{\pi}$ & $100 \times \sigma_{x}$ \\
\hline RBC & & - & 0.000 & 0.000 \\
FF & Ramsey 2 var. & 0.000 & 0.000 & 0.000 \\
$"$ & Ramsey 1 var. & 0.001 & 0.006 & 0.093 \\
$"$ & Aug. Taylor rule & 0.004 & 0.036 & 0.413 \\
$"$ & Investment tax & 0.009 & 0.072 & 0.080 \\
$"$ & Taylor rule & 0.020 & 0.111 & 0.214 \\
$"$ & Leverage tax & 0.037 & 0.141 & 0.512 \\
\hline
\end{tabular}

Table 5: Consumption-equivalent welfare costs under different policies, relative to the flexible price RBC model. A positive figure indicates a welfare loss relative to the first-best. "RBC" refers to the perfect competition, flexible price $\mathrm{RBC}$ model, and "FF" to the model with both the financial friction and the nominal rigidity. "Ramsey 2 var.": Ramsey policy which sets inflation rate and investment level. "Ramsey 1 var.": Ramsey policy which sets inflation rate only. "Augmented Taylor rule": Taylor rule reacting to inflation, output gap and real capital price. "Investment subsidy": Standard Taylor rule and investment tax/subsidy. "Taylor rule": Standard Taylor rule reacting to inflation and output gap. "Leverage tax": Standard Taylor rule and leverage tax/subsidy. $\sigma_{\pi}$ : Standard deviation of inflation. $\sigma_{x}$ : Standard deviation of output gap.

First, the welfare costs compared to the first-best allocation are small in absolute terms under any policy regime. For example, the worst-performing policy (entitled "Leverage tax" in the table) results in a welfare cost of $0.04 \%$ of consumption in each period compared to the first-best. This magnitude is in line with many earlier studies comparing welfare effects of different monetary policy regimes. ${ }^{10}$ The welfare analysis allows, however, to order the different policies by welfare losses and thus compare their desirability in qualitative terms.

Notably, as was demonstrated in Section 4.3, a Ramsey planner who can optimally set both the inflation and the investment level, can replicate the first-best allocation: the welfare cost to the household under this policy regime is zero, and both inflation and output gap are fully stabilised. The availability of two distinct policy variables is required to offset both frictions in the economy. This result is demonstrated in the second row of Table 5.

The single-variable Ramsey problem, where the planner can only set the in-

\footnotetext{
${ }^{10}$ The seminal discussion by Lucas (2003) finds consumption-equivalent welfare gains from eliminating business cycle fluctuations, in general, to be roughly in the order of magnitude of $0.05 \%$.
} 
flation rate, is nested within the two-variable problem. Interestingly, when there are financial frictions in the economy, it is optimal to focus on stabilising inflation, but not the output gap, as shown in the third row of the table: the standard deviation of inflation is very close to zero, while the standard deviation of output gap is clearly positive. Thus some deviation from the first-best output is traded off for price stability.

The rule-based policies do not fall far behind in welfare levels compared to the two Ramsey policies. The best regime is the augmented Taylor rule, shown on the fourth row of the table, and second comes the policy mix that which combines a standard Taylor rule for monetary policy with an investment tax/subsidy, shown on the fifth row. These two policies come very close to the Ramsey-optimal policy plans in terms of welfare losses. The augmented Taylor rule achieves a very low inflation volatility, but a relatively high output gap volatility.

The welfare evaluation seems to somewhat contradict earlier results in monetary policy literature. The general view in the literature is that the central bank need not concern itself with asset price fluctuations, except insofar as they reflect changes expected inflation. ${ }^{11}$ In this model, even when prices are fully flexible, the fluctuations of real asset prices reflect the sub-optimal levels of investment caused by the agency cost, and it is beneficial for the policymaker to react to them.

The economy where both an interest rate rule and a rule-based leverage tax is in use fares the worst in terms of household welfare. As discussed in Section 5.3 , the cyclical leverage tax is counter-productive except when stabilising financial shocks. This is confirmed by the fact that inflation is more volatile when the tax rule is active than when it is not. It is thus not surprising that when such a rule is always active, it is detrimental for household welfare.

\section{Concluding remarks}

This paper investigates the policy implications of jointly setting monetary and macroprudential policies when there are important financial frictions in the economy.

\footnotetext{
${ }^{11}$ See for example Iacoviello (2005) and Carlstrom and Fuerst (2007).
} 
The first main finding is that with both a nominal and a financial frictions, a social planner needs two separate choice variables to replicate the first-best outcome. With two policy variables - a monetary and a financial one - the constrained optimum is efficient. When the Ramsey planner can only set the inflation rate, he cannot fully stabilise the economy but a policy trade-off between stabilising inflation and output gap remains.

This result suggests that there could be a need for two distinct policies also when the Ramsey policy solution is not available. Different policy regimes with simple rules are analysed: one with no macroprudential policy; one with a single monetary instrument which also reacts to financial developments; and two regimes with separate monetary and macroprudential instruments.

The second important finding is that a policy regime where the monetary authority adjusts the nominal interest rate also in reaction to real asset prices, besides inflation and output gap, performs well in this model economy. This suggests that a unified mandate, whereby monetary policy pays attention to financial developments, could be useful. Especially when shocks other than financial ones - such as technology or demand shocks - are the main drivers of business cycles, it is seems that conventional interest-rate-based monetary policy is enough to deal with cyclical fluctuations, if the monetary authority reacts to financial market conditions.

However, if there are important fluctuations arising from financial shocks, the availability of a separate macroprudential tool enhances the effectiveness of policy in stabilising the economy. The policy supporting credit intermediation can remove inflationary pressures and leave the monetary policy to deal with inflation. The specific policy needs to be designed carefully to avoid conflicts with monetary policy; controlling the price instead of the quantity of banks' investment opportunities could be preferrable.

Finally, the analysis reveals that the sector of origin and the cause of cyclical fluctuations in the economy matter a great deal for the appropriate policy mix to be used. This suggests that there are considerable gains from properly coordinating the use of macroprudential policy with conventional monetary policy.

The limitations of the present framework relate to the fact that it is a representative agent model without default. Thus, the "stability" of the financial 
system has to be interpreted as the credit conditions implied by the agency problem. A macroprudential policy should, in this context, be understood as one that seeks to minimise the agency costs in credit intermediation to guarantee that investments reach their efficient level. 


\section{A Impulse responses to the preference shock}
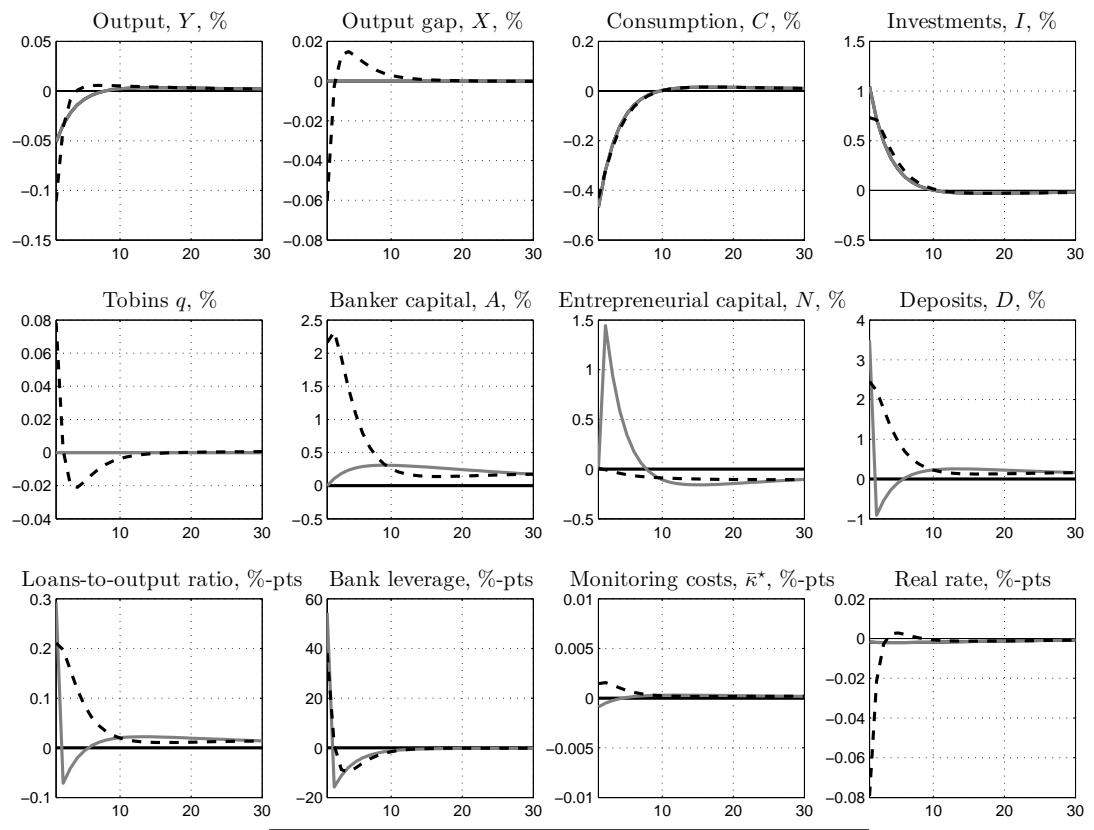

- Flexible price RBC —C Constrained-optimal RBC - - - No intervention

Figure 7: Effects of a one percent negative total factor productivity shock in the RBC model under the Ramsey policy. "Flexible price RBC": model with fully flexible prices and no financial friction. "Constrained-optimal RBC": model with fully flexible prices, but with the financial friction; policy intervention by the planner. 

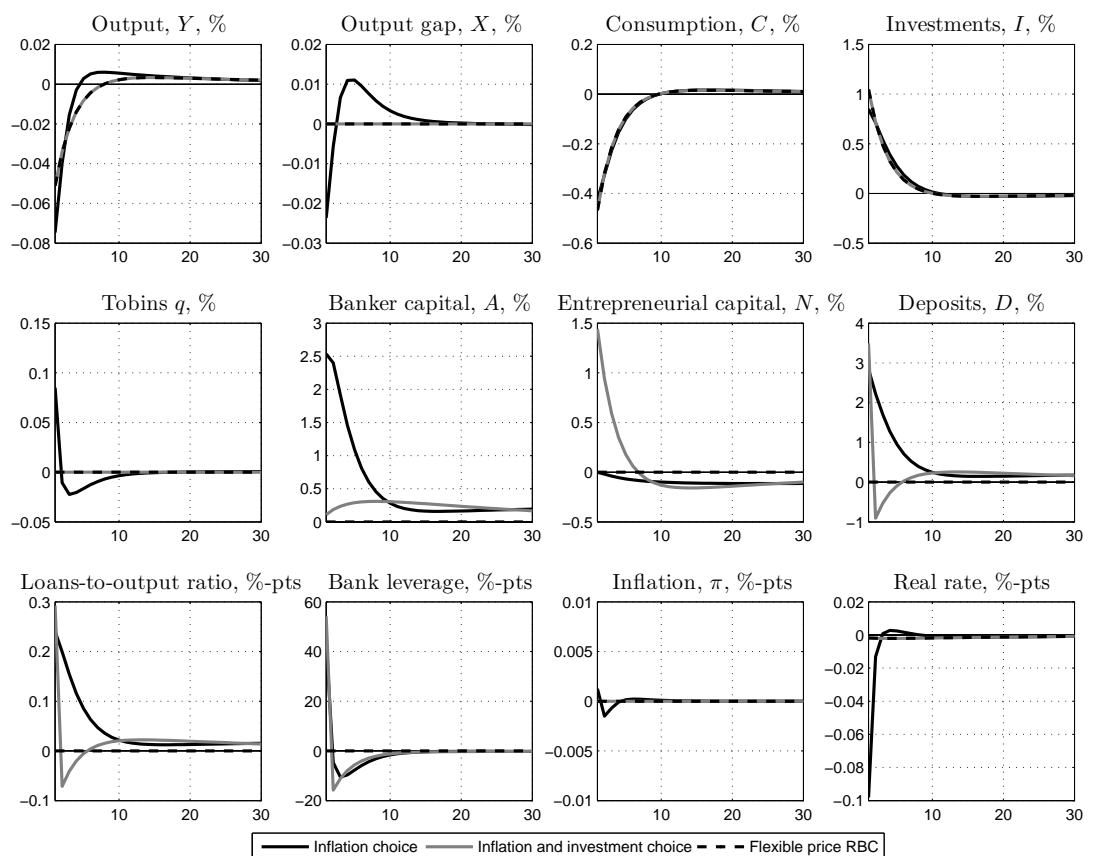

Figure 8: Effects of a one percent negative demand (preference) shock in the New Keynesian model under Ramsey policy. "Inflation choice": model with sticky prices and the financial friction; social planner sets the inflation rate. "Inflation and investment choice": model with sticky prices and the financial friction; social planner sets the inflation rate and the level of investments. "Flexible price RBC": the frictionless flexible price (first-best) benchmark. 

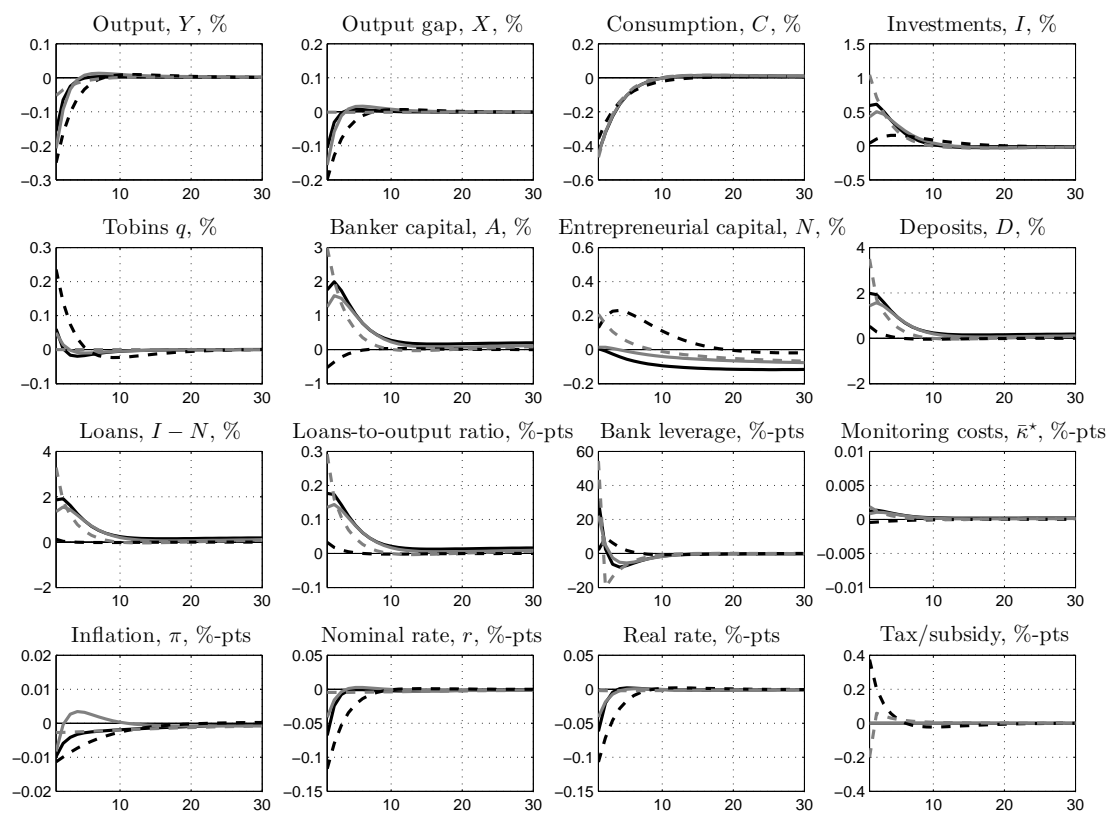

Figure 9: Policy response to a one percent adverse demand (preference) shock under rule-based policies. "Taylor rule": the financial frictions model with standard Taylor rule that reacts to inflation and output gap; "Augmented Taylor rule": the financial frictions model with an augmented Taylor rule that reacts to inflation, otuput gap and real capital price; "Leverage tax": the financial frictions model with standard Taylor rule and leverage tax; "Investment tax": the financial frictions model with standard Taylor rule and investment subsidy. "Tax/subsidy" panel: a positive figure indicates a tax, a negative figure a subsidy. 


\section{B Summary of the model}

\section{B.1 The dynamic equilibrium conditions}

This section summarises the dynamic model equations.

\section{B.1.1 The macro block}

The household's optimality conditions are:

$$
\begin{aligned}
w_{t} & =\frac{\chi L_{t}^{\theta}}{U_{C}\left(C_{t}, L_{t}\right)} & & \text { (Labour supply) } \\
1 & =\beta E_{t}\left[\frac{U_{C}\left(C_{t+1}, L_{t+1}\right)}{U_{C}\left(C_{t}, L_{t}\right)} \frac{1+r_{t}}{\pi_{t+1}}\right] & & \text { (Bond Euler eq.) } \\
q_{t} & =\beta E_{t}\left[\frac{U_{C}\left(C_{t+1}, L_{t+1}\right)}{U_{C}\left(C_{t}, L_{t}\right)}\left(r_{t+1}^{K}+(1-\delta) q_{t+1}\right)\right] & & \text { (Capital Euler eq.) }
\end{aligned}
$$

where $U_{C}\left(C_{t}, L_{t}\right)=Z_{t}^{c}\left[\frac{1}{1-b}\left(C_{t}-b C_{t-1}\right)\right]^{-\sigma}$ and $\log Z_{t}^{c}=\phi_{c} \log Z_{t-1}^{c}+\epsilon_{t}^{c}$, $\epsilon_{t}^{c} \sim N\left(0, \sigma_{c}^{2}\right)$, i.i.d.

The symmetric equilibrium conditions of the intermediate production sector are:

$$
\begin{array}{rrr}
\frac{r_{t}^{K}}{w_{t}} & =\frac{\alpha L_{t}(j)}{(1-\alpha) K_{t}(j)} & \text { (Relative factor price) } \\
\psi_{t} & =\left(\frac{r_{t}^{K}}{\alpha}\right)^{\alpha}\left(\frac{w_{t}}{1-\alpha}\right)^{(1-\alpha)} Z_{t}^{-1} & \text { (Real marginal cost) } \\
\frac{P_{t}^{*}}{P_{t}} & =\frac{\varepsilon}{\varepsilon-1} \frac{E_{t} \sum_{k=0}^{\infty} \omega^{k} Q_{t, t+k} \psi_{t+k \mid t} Y_{t+k \mid t} \pi_{t+k}^{\varepsilon+1}}{E_{t} \sum_{k=0}^{\infty} \omega^{k} Q_{t, t+k} Y_{t+k \mid t} \pi_{t+k}^{\varepsilon}} & \text { (Optimal pricing) }
\end{array}
$$

where $Q_{t, t+k} \equiv \beta^{k} \frac{U_{C}\left(C_{t+1}, L_{t+1}\right)}{U_{C}\left(C_{t}, L_{t}\right)} \frac{P_{t}}{P_{t+k}}$ and $\log Z_{t}=\phi \log Z_{t-1}+\epsilon_{t}, \epsilon_{t} \sim$ $N\left(0, \sigma^{2}\right)$, i.i.d.

Furthermore, the numerator of the optimal pricing decision can be reformulated recursively as:

$$
\operatorname{Num}_{t}=\psi_{t} Y_{t}+\omega\left(1+r_{t}\right)^{-1} E_{t} \pi_{t+1}^{\varepsilon+1} \mathrm{Num}_{t+1},
$$


and the denominator as:

$$
\operatorname{Denom}_{t}=Y_{t}+\omega\left(1+r_{t}\right)^{-1} E_{t} \pi_{t+1}^{\varepsilon} \text { Denom }_{t+1},
$$

which allows expressing the optimal price relative to the aggregate price level recursively (for computational convenience) as:

$$
\frac{P_{t}^{*}}{P_{t}}=\frac{\varepsilon}{\varepsilon-1} \frac{\mathrm{Num}_{t}}{\text { Denom }_{t}} .
$$

The aggregate dynamic equilibrium conditions are:

$$
\begin{aligned}
& Y_{t}=Z_{t} K_{t}^{\alpha}\left(L_{t}\right)^{1-\alpha} \\
& \text { (Aggregate production) } \\
& Y_{t}=\left(C_{t}+I_{t}\right) s_{t} \\
& \text { (Aggregate consistency constraint) } \\
& s_{t}=(1-\omega)\left(\frac{P_{t}^{*}}{P_{t}}\right)^{-\varepsilon}+\omega \pi_{t}^{\varepsilon} s_{t-1} \quad \text { (Correction for price dispersion) } \\
& K_{t+1}=p_{H} R I_{t}+(1-\delta) K_{t} \\
& \text { (Capital accumulation) } \\
& P_{t}=\left[\omega P_{t-1}^{1-\varepsilon}+(1-\omega)\left(P_{t}^{*}\right)^{1-\varepsilon}\right]^{\frac{1}{1-\varepsilon}} \\
& 1=\omega \pi_{t}^{\varepsilon-1}+(1-\omega)\left(\frac{P_{t}^{*}}{P_{t}}\right)^{1-\varepsilon} \\
& \text { (Aggregate price level) } \\
& \text { (Price dispersion) }
\end{aligned}
$$

\section{B.1.2 The financial block}

The aggregate equilibrium in the financial sector is described by the following equations. 


$$
\begin{aligned}
& \kappa_{t}^{*}=\frac{\gamma \rho_{t}}{1+\frac{p_{H}}{\Delta p}\left(\frac{1}{1+r_{t}}-\frac{1}{1+r_{t}^{a}}\right)} \\
& b\left(\kappa_{t}^{*}\right)=\Gamma\left(\kappa_{t}^{*}\right)^{-\frac{\gamma}{1-\gamma}} \\
& \rho_{t}=\frac{q_{t} p_{H} R}{1+r_{t}}-1 \\
& g_{t}=\frac{p_{H}}{\Delta p} \frac{b\left(\kappa_{t}^{*}\right)}{1+r_{t}}-(1-\gamma) \rho_{t} \quad \text { (Entrepreneur's inverse leverage ratio) } \\
& R_{t}^{e}=\frac{b\left(\kappa_{t}^{*}\right)}{q_{t} \Delta p} \\
& R_{t}^{b}=\frac{\kappa_{t}^{*}}{q_{t} \Delta p} \\
& R_{t}^{w}=R-R_{t}^{e}-R_{t}^{b} \\
& 1+r_{t}^{a}=\frac{p_{H}}{\Delta p} \kappa_{t}^{*} \frac{I_{t}}{A_{t}} \\
& 1+r_{t}^{e}=\frac{p_{H}}{\Delta p} b\left(\kappa_{t}^{*}\right) \frac{I_{t}}{N_{t}} \\
& I_{t}=\frac{N_{t}}{g_{t}} \\
& N_{t+1}=\lambda^{e}\left(1+r_{t}^{e}\right) \frac{r_{t+1}^{K}+(1-\delta) q_{t+1}}{q_{t}} N_{t} \\
& \text { (Accumulation of entrepreneur's net worth) } \\
& A_{t+1}=Z_{t}^{b} \lambda^{b}\left(1+r_{t}^{a}\right) \frac{r_{t+1}^{K}+\left(1-\delta_{t}\right) q_{t+1}}{q_{t}} A_{t} \\
& \text { (Entrepreneur's return share) } \\
& \text { (Banker's return share) } \\
& \text { (Worker's return share) } \\
& \text { (Return on bank capital) } \\
& \text { (Return on entrepreneurial capital) } \\
& \text { (Investment size) }
\end{aligned}
$$

where $\log Z_{t}^{b}=\phi_{b} \log Z_{t-1}^{b}+\epsilon_{t}^{b}, \epsilon_{t}^{b} \sim N\left(0, \sigma_{b}^{2}\right)$, i.i.d.

\section{B.1.3 Government policy}

Finally, the model is closed by the Taylor rule for the nominal interest rate, and the rule for the macroprudential policy. 


$$
\begin{array}{rr}
1+r_{t}=\frac{1}{\beta} \pi_{t}^{\phi_{\pi}} \tilde{x}_{t}^{\phi_{x}} q_{t}^{\phi_{q}} & \text { (Taylor rule) } \\
1+\tau_{t}=\tilde{\Upsilon}_{t}^{\phi_{\Upsilon}} & \text { (Leverage tax rule) } \\
1+\varsigma_{t}=\left[1+r_{t}+\gamma^{-1} \kappa_{t}^{*}\left(1+r_{t}+\frac{p_{H}}{\Delta p}\left(1-\frac{1+r_{t}}{1+r_{t}^{a}}\right)\right)\right]\left(p_{H} R\right)^{-1}
\end{array}
$$

(Investment subsidy)

Here, $\tilde{x_{t}} \equiv \frac{Y_{t}}{Y_{t}^{e}}$ is the output gap and $\tilde{\Upsilon}_{t} \equiv \frac{\left(I_{t}-N_{t}\right) / Y_{t}}{(I-N) / Y}$ is the deviation of the loans-to-output ratio from its steady state value, or the "credit gap".

\section{B.2 Deterministic steady state}

The deterministic steady state of the model is as follows. It is assumed that a steady state employment subsidy is in place such that $\mu=1$, so that the steady state is not distorted by the monopolistic competition.

\section{B.2.1 The macro block}

The steady state of the macro block of the model is: 


$$
\begin{aligned}
& 1+r=\frac{1}{\beta} \\
& P^{*}=P=1 \\
& \pi=1 \\
& s=1 \\
& \psi=1 \\
& q=\frac{1+\rho}{\beta p_{H} R} \\
& r^{K}=q(r+\delta) \\
& w=(1-\alpha)\left(\frac{r^{K}}{\alpha}\right)^{\frac{\alpha}{\alpha-1}} \\
& K=\left[\left(\frac{r^{K}}{\alpha}\right)^{\frac{\theta+\alpha}{\alpha-1}} \frac{1-\alpha}{\chi}\left(\frac{r^{K}}{\alpha}-\frac{\delta}{p_{H} R}\right)^{-\sigma}\right]^{\frac{1}{\theta+\sigma}} \\
& L=K\left(\frac{r^{K}}{\alpha}\right)^{\frac{1}{1-\alpha}} \\
& Y=\frac{r^{K} K}{\alpha} \\
& I=\frac{\delta K}{p_{H} R} \\
& C=Y-I \\
& \tau=0 \\
& Z=Z^{c}=Z^{b}=1
\end{aligned}
$$

The steady state is non-distorted and identical to the efficient steady state (where prices are assumed flexible and there is no financial friction in investment) when $q=1$. The efficient steady state can thus be replicated by imposing a steady state investment subsidy on the gross return of the investment project, $R$. Denote this subsidy by $1+\varsigma$. Then, the subsidy needed to replicate the efficient steady state is:

$$
q=\frac{1+\rho}{\beta p_{H} R(1+\varsigma)}=1 \quad \Leftrightarrow \quad \varsigma=\frac{1}{\beta}-1+\frac{\rho}{\beta}=r+\frac{\rho}{1+r} .
$$




\section{B.2.2 The financial block}

The steady state of the financial block of the model is:

$$
\begin{gathered}
1+r^{a}=\frac{\beta}{\lambda^{b}} \\
1+r^{e}=\frac{\beta}{\lambda^{e}} \\
R^{b}=\frac{c^{*}}{q \Delta p} \\
R^{e}=\frac{b\left(c^{*}\right)}{q \Delta p} \\
R^{w}=R-R^{e}-R^{b} \\
c^{*}=\left(\Gamma \frac{\gamma}{1-\gamma}\right)^{1-\gamma}\left(\frac{\beta-\frac{\lambda^{e}}{\beta}}{\beta-\frac{\lambda^{b}}{\beta}+\frac{\Delta p}{p_{H}}}\right)^{1-\gamma} \\
b\left(c^{*}\right)=\Gamma\left(c^{*}\right)^{-\frac{\gamma}{1-\gamma}} \\
\rho=\frac{c^{*}}{\gamma}\left[1+\frac{p_{H}}{\Delta p}\left(\beta-\frac{\lambda^{b}}{\beta}\right)\right] \\
g=\beta \frac{p_{H}}{\Delta p} b\left(c^{*}\right)-(1-\gamma) \rho \\
A=\frac{\lambda^{b}}{\beta} \frac{p_{H}}{\Delta p} c^{*} I \\
N=\frac{\lambda^{e}}{\beta} \frac{p_{H}}{\Delta p} b^{*} I
\end{gathered}
$$

\section{The Ramsey problem}

The problem of the Ramsey planner can be formulated as follows. Let $y_{t}$ be a vector containing the $n$ endogenous variables of the economy, including the planner's choice variables, and $u_{t}$ the vector of exogenous variables. The agents in the economy optimise taking the planner's choice variables (the policy variables) as given. The equilibrium of the private economy is described by the $m$ first-order conditions and transition equations:

$$
E_{t}\left[f\left(y_{t-1}, y_{t}, y_{t+1}, u_{t}\right)\right]=0 .
$$


This leaves $n-m$ choice variables for the planner.

The Ramsey planner chooses the values of the policy variables in each period to maximise household welfare, subject to the economy's equilibrium conditions:

$$
\begin{array}{ll} 
& \max _{\left\{y_{\tau}\right\}_{\tau=t}^{\infty}} E_{\tau} \sum_{\tau=t}^{\infty} \beta^{\tau-t} U\left(C_{\tau}, L_{\tau}\right) \\
\text { s.t. } & E_{\tau}\left[f\left(y_{\tau-1}, y_{\tau}, y_{\tau+1}, u_{\tau}\right)\right]=0 \quad \forall \tau \in\{\ldots, t-1, t, t+1, \ldots\} .
\end{array}
$$

In other words, the Ramsey planner chooses a competitive equilibrium that maximises household welfare.

\section{The welfare measure}

The welfare cost of the different policy measures are computed as consumption equivalent costs relative to a benchmark policy as described in SchmittGrohé and Uribe (2006).

Define the welfare of the household under the benchmark allocation (denoted by $R$ ), conditional on the state of the economy at time zero, as

$$
V_{0}^{R}=E_{0} \sum_{t=0}^{\infty} \beta^{t} U\left(C_{t}^{R}, L_{t}^{R}\right),
$$

where $C_{t}^{R}$ and $L_{t}^{r}$ denote the plans for consumption and hours worked under the benchmark policy regime.

Similarly, define the conditional welfare under an alternative policy plan (denoted by $A$ ) as

$$
V_{0}^{A}=E_{0} \sum_{t=0}^{\infty} \beta^{t} U\left(C_{t}^{A}, L_{t}^{A}\right) .
$$

Assume that at time zero, all variables are equal to their steady-state values. Since the steady state of the model is undistorted and unaffected by the different policy regimes, the initial state of the economy is the same for the benchmark and the alternative policies.

Next, denote by $x$ the consumption-equivalent conditional welfare cost of the 
alternative policy regime, relative to the benchmark regime. Formally, the $\operatorname{cost} x$ is implicitly defined by:

$$
V_{0}^{A}=E_{0} \sum_{t=0}^{\infty} \beta^{t} U\left((1-x) C_{t}^{R}, L_{t}^{R}\right)
$$

Using the CES functional form for periodic utility and solving for $x$ yields:

$$
\begin{aligned}
V_{0}^{A} & =E_{0} \sum_{t=0}^{\infty} \beta^{t}\left[Z_{t}^{c} \frac{\left((1-x) C_{t}^{R}\right)^{1-\sigma}}{1-\sigma}-\frac{\chi\left(L_{t}^{R}\right)^{1+\theta}}{1+\theta}\right] \\
& =E_{0} \sum_{t=0}^{\infty} \beta^{t}\left[\left((1-x)^{1-\sigma}-1\right) Z_{t}^{c} \frac{\left(C_{t}^{R}\right)^{1-\sigma}}{1-\sigma}\right]+V_{0}^{R} \\
\Leftrightarrow \quad x & =1-\left[1+\frac{V_{0}^{A}-V_{0}^{R}}{E_{0} \sum_{t=0}^{\infty} \beta^{t} Z_{t}^{c} \frac{\left(C_{t}^{R}\right)^{1-\sigma}}{1-\sigma}}\right]^{\frac{1}{1-\sigma}} .
\end{aligned}
$$

Note that when $V_{0}^{A}=V_{0}^{R}$, the measure equals zero.

Simulating the models for a long enough time horizon $T$ and repeating the simulation $N$ times, for $N$ large enough, yields an estimate of the conditional expectations $V_{0}^{R}$ and $V_{0}^{A}$, which allows to numerically estimate the cost $x$. 


\section{References}

Adrian, T. and H. S. Shin (2010). Financial intermediaries and monetary policy. In B. M. Friedman and M. Woodford (Eds.), Handbook of Monetary Economics, Volume 3, pp. 601-650. Elsevier, Amsterdam.

Albertazzi, U. and L. Gambacorta (2009). Bank profitability and the business cycle. Journal of Financial Stability 5, 393-409.

Angelini, P., S. Neri, and F. Panetta (2014). The interaction between capital requirements and monetary policy. Journal of Money, Credit and Banking 46, 1073-1112.

Angeloni, I. and E. Faia (2013). Capital regulation and monetary policy with fragile banks. Journal of Monetary Economics 60, 311-324.

Bank of England (2009). The role of monetary policy. Bank of England Discussion Papers. 19 November 2009.

Bank of International Settlements (2011). Macroprudential policy - a literature review. BIS Discussion Papers $33 \%$.

Basel Committee on Banking Supervision (2010). Basel III: A global regulatory framework for more resilient banks and banking systems. Bank for International Settlements Publications. December 2010, revised in June 2011.

Calvo, G. A. (1983). Staggered prices in a utility-maximizing framework. Journal of Monetary Economics 12, 383-398.

Canzoneri, M., F. Collard, H. Dellas, and B. Diba (2011). Fiscal multipliers in recessions. Mimeo.

Carlstrom, C. T. and T. S. Fuerst (2007). Asset prices, nominal rigidities, and monetary policy. Review of Economic Dynamics 10, 256-275.

Chen, N.-K. (2001). Bank net worth, asset prices and economic activity. Journal of Monetary Economics 48, 415-436.

Christensen, I., C. Meh, and K. Moran (2011). Bank leverage regulation and macroeconomic dynamics. Bank of Canada Working Paper 32. 
Collard, F., H. Dellas, B. Diba, and O. Loisel (2012). Optimal monetary and prudential policies. Banque de France Working Paper 413.

Cúrdia, V. and M. Woodford (2010a). Conventional and unconventional monetary policy. Federal Reserve Bank of St. Louis Review 92, 229-264.

Cúrdia, V. and M. Woodford (2010b). Credit spreads and monetary policy. Journal of Money, Credit and Banking 42 (s1), 3-35.

Cúrdia, V. and M. Woodford (2011). The central bank balance sheet as an instrument of monetary policy. Journal of Monetary Economics 58, 54-79.

European Commission (2012). A roadmap towards a banking union. Communication from the Commission to the European Parliament and the Council COM(2012) 510. 12 September 2012.

Faia, E. (2010). Credit risk transfer and the macroeconomy. European Central Bank Working Paper 1256.

Faia, E. and T. Monacelli (2007). Optimal interest rate rules, asset prices, and credit frictions. Journal of Economic Dynamics and Control 31, 32283254 .

Gertler, M. and P. Karadi (2011). A model of unconventional monetary policy. Journal of Monetary Economics 58, 17-34.

Gertler, M. and N. Kiyotaki (2010). Financial intermediation and credit policy in business cycle analysis. In B. M. Friedman and M. Woodford (Eds.), Handbook of Monetary Economics, Volume 3, pp. 547-599. Elsevier, Amsterdam.

Gertler, M. and N. Kiyotaki (2013). Banking, liquidity and bank runs in an infinite horizon economy. Mimeo.

Haavio, M., A. Ripatti, and T. Takalo (2015). Macroeconomic effects of bank recapitalizations. Mimeo.

Holmström, B. and J. Tirole (1997). Financial intermediation, loanable funds, and the real sector. The Quarterly Journal of Economics 112, 663-691.

Iacoviello, M. (2005). House prices, borrowing constraints, and monetary policy in the business cycle. American Economic Review 95, 739-764. 
Kalemli-Ozcan, S., B. Sorensen, and S. Yesiltas (2011). Leverage across firms, banks, and countries. NBER Working Paper series 17354.

Lucas, R. E. (2003). Macroeconomic priorities. American Economic Review 93, 1-14.

Meh, C. A. and K. Moran (2010). The role of bank capital in the propagation of shocks. Journal of Economic Dynamics and Control 34, 555-576.

Monacelli, T. (2006). Optimal monetary policy with collateralized household debt and borrowing constraints. Mimeo. Prepared for the NBER Monetary Policy and Asset Prices conference, May 5-6 2006.

Philippon, T. (2014). Has the U.S. finance industry become less efficient? on the theory and measurement of financial intermediation. CEPR Discussion Paper 9792.

Schmitt-Grohé, S. and M. Uribe (2006). Optimal simple and implementable monetary and fiscal rules: Expanded version. NBER Working Paper 12402.

World Bank (2013). Global financial developments. http://data. worldbank.org/data-catalog/global-financial-development/. Accessed February 6, 2015. 